Article

\title{
Novel Liquid Chitosan-Based Biocoagulant for Treatment Optimization of Fish Processing Wastewater from a Moroccan Plant
}

\author{
Nisrine Nouj ${ }^{1, *}$, Naima Hafid ${ }^{1}$, Noureddine El Alem ${ }^{1}$ and Igor Cretescu ${ }^{2, *}$ (i) \\ 1 Material and Environmental Laboratory, Department of Chemistry, Faculty of Sciences of Agadir, \\ IBN ZOHR University, Agadir 80000, Morocco; hafidnaima@yahoo.fr (N.H.); n.elalem@uiz.ac.ma (N.E.A.) \\ 2 Department of Environmental Engineering and Management, Faculty of Chemical Engineering and \\ Environmental Protection, "Gheorghe Asachi” Technical University of Iasi, 700050 Iasi, Romania \\ * Correspondence: nouj.nisrine@gmail.com (N.N.); icre1@yahoo.co.uk (I.C.)
}

Citation: Nouj, N.; Hafid, N.; El Alem, N.; Cretescu, I. Novel Liquid Chitosan-Based Biocoagulant for Treatment Optimization of Fish Processing Wastewater from a Moroccan Plant. Materials 2021, 14, 7133. https://doi.org/10.3390/ ma14237133

Academic Editor: Frank Lipnizki

Received: 23 October 2021

Accepted: 16 November 2021

Published: 23 November 2021

Publisher's Note: MDPI stays neutral with regard to jurisdictional claims in published maps and institutional affiliations.

Copyright: (C) 2021 by the authors. Licensee MDPI, Basel, Switzerland. This article is an open access article distributed under the terms and conditions of the Creative Commons Attribution (CC BY) license (https:// creativecommons.org/licenses/by/ $4.0 /)$.

\begin{abstract}
A novel liquid chitosan-based biocoagulant for treating wastewater from a Moroccan fish processing plant was successfully prepared from shrimp shells (Parapenaeus longirostris), the most abundant fish by-products in the country. The shells were characterized using scanning electron microscopy, energy-dispersive X-ray spectroscopy, X-ray diffraction, and Fourier transforms infrared spectroscopy. Using chitosan without adding acetic acid helps to minimize its negative impact on the environment. At the same time, the recovery of marine shellfish represents a promising solution for the management of solid fish waste. In order to test the treatment efficiency of the biocoagulant developed, a qualitative characterization of these effluents was carried out beforehand. The optimization process was conducted in two steps: jar-test experiments and modeling of the experimental results. The first step covered the preliminary assessment to identify the most influential operational parameters (experimental conditions), whereas the second step concerned the study of the effects of three significant operational parameters and their interactions using a Box-Behnken experimental design. The variables involved were the concentration of coagulant $\left(\mathrm{X}_{1}\right)$, the initial $\mathrm{pH}\left(\mathrm{X}_{2}\right)$, and the temperature $\left(\mathrm{X}_{3}\right)$ of the wastewater samples, while the responses were the removal rates of turbidity $\left(\mathrm{Y}_{1}\right)$ and $\mathrm{BOD}_{5}\left(\mathrm{Y}_{2}\right)$. The regression models and response surface contour plots revealed that chitosan as a liquid biocoagulant was effective in removing turbidity $(98 \%)$ and $\mathrm{BOD}_{5}$ (53\%) during the treatment. The optimal experimental conditions were found to be an alkaline media $(\mathrm{pH}=10.5)$ and a biocoagulant dose of $5.5 \mathrm{~mL}$ in $0.5 \mathrm{~L}$ of fish processing wastewater maintained at $20{ }^{\circ} \mathrm{C}$.
\end{abstract}

Keywords: biocoagulation; seafood processing wastes; fish by-products; industrial effluents; response surface methodology; Box-Behnken experimental design

\section{Introduction}

Wastewater effluents from fish processing plants (fish processing wastewater, FPW) present an environmental issue because of complications in their treatment due to the different components presented in the effluents. This sector generates USD 207,407,800.00 per year on export [1]. In Morocco, the subject of this study, the effluent volume is not only increasing, but the fish processing industry is also responsible for a large quantity of fishrelated solid wastes, including bones, skins, scales, fins, and swim bladders, constituting $36 \%$ (and maybe representing up to $60 \%$ ) of the raw material mass [2,3]. These solid wastes could be potential sources of income if sufficient assessment is carried out. At the same time, the production units generate wastewater that harms the environment, and this must be treated before discharge. As a result, the rejected by-products can be involved (by using the proposed methodology) in the preparation of products for wastewater treatment.

Different processes were carried out to treat this wastewater in order to protect the environment. Among the possible treatments, there is coagulation-flocculation; the most 
widely used process, and which addresses the need to replace chemical coagulants with natural ones to preserve the environment. In order to find a natural coagulant, chitosan was used in many studies and for many applications [4,5]; including its extraction from the most abundant fish by-products: shrimp shells, especially Parapenaeus longirostris [6]. Valuing this waste for its contents is a solution to reduce fish solid waste [6]. Chitosan, as a biomaterial, represents the most well-known natural coagulant. Biocoagulants are mainly used to minimize the use of chemical coagulants. Chitosan powder is dissolved using acetic acid to treat wastewater. Various types of wastewater from the food industry have been treated using chitosan, such as meat [7], dairy products [7,8], bagasse [9], and egg [10], as well as various turbid natural waters [11]. It shows a removal rate between $70 \%$ and $90 \%$ for the total suspended solids content (TSS), and between $83 \%$ and $84 \%$ for the biological oxygen demand $\left(\mathrm{BOD}_{5}\right)$, as basic forms used for measuring pollution in these cases.

In this context, this study is focused on the efficiency enhancement of the treatment plants for fish processing wastewater using biocoagulation, based on a fishery by-product (shrimp shell) in a liquid state. Using liquid chitosan minimizes the use of acetic acid and leads to more respect for the environment [12]. The effect of physicochemical parameters (initial $\mathrm{pH}$, liquid chitosan dosage, turbidity, and biochemical oxygen demand) was studied in terms of the performance of the biocoagulation process using a Box-Behnken experimental design.

\section{Materials and Methods}

This study is divided into two parts. The first part concerns the preparation of liquid chitosan from shrimp shells (Parapenaeus longirostris [6]), while the second part is related to the modeling and optimization of the fish processing wastewater treatment with a biocoagulation process using the above mentioned chitosan-based biocoagulant.

\subsection{Collection of Wastewater and Shrimp Exoskeleton Samples}

Wastewater effluent samples were collected at a fish processing plant located in the industrial area of Anza, Agadir city, Morocco. The samples were stored at $4.0 \pm 3{ }^{\circ} \mathrm{C}$ for a period of $48 \mathrm{~h}$ after collection, before determining the physicochemical qualities of the effluents (temperature, $\mathrm{pH}$, turbidity, and biological oxygen demand over 5 days $\left(\mathrm{BOD}_{5}\right)$ ) using the 'Standard methods for water and wastewater, APHA, 2017' [13].

The Parapenaeus longirostris exoskeletons used in this study came from a local market in Agadir city in southern Morocco. The shrimp shells were repeatedly washed with water to remove the parts of the pulp and viscera stuck to the exoskeleton. The shrimp shells were dried at $220^{\circ} \mathrm{C}$ for $15 \mathrm{~min}$ (Figure 1a), then crushed and carefully sieved to a size of $500 \mu \mathrm{m}$.

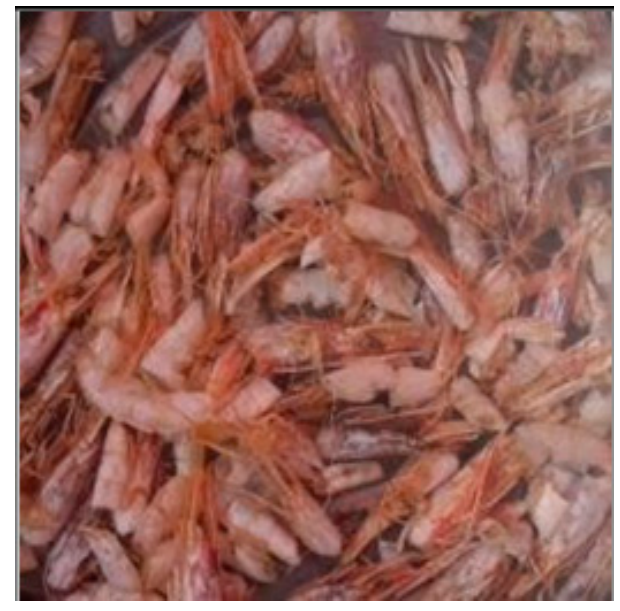

(a)

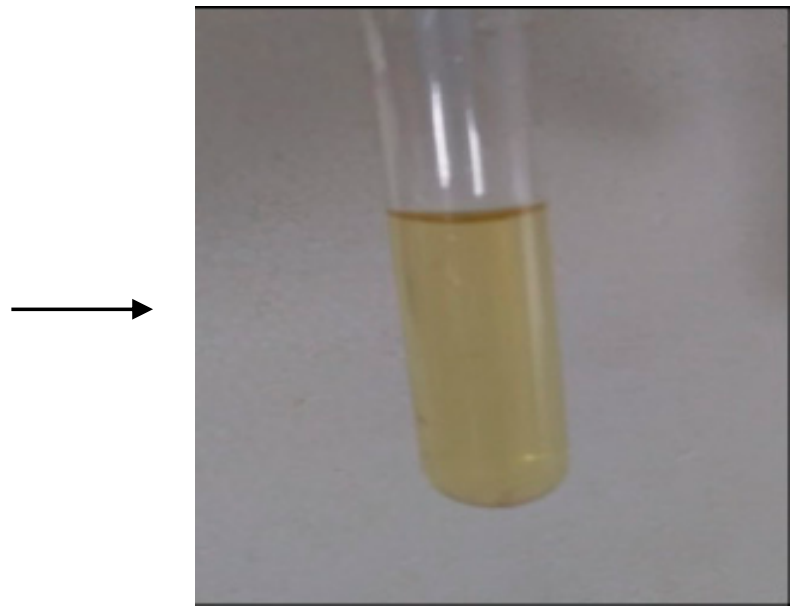

(b)

Figure 1. Transformation of shrimp shells to liquid chitosan: (a) dried shrimp exoskeleton; (b) liquid chitosan. 


\subsection{Preparation of the Natural Coagulant}

The chitosan amino functionality leads to chemical reactions such as grafting, acetylation, chelation of metals, quaternization, and reactions with aldehydes and ketones, etc. to offer a variety of products with different properties, such as being non-toxic, antiulcer, non-allergenic, anti-acid, anti-fungal, antibacterial, andanti-viral, as well as total biodegradability and biocompatibility, etc. [14]. The antimicrobial property of chitosan is strongly affected by parameters such as $\mathrm{pH}$ [15]; therefore, the liquid chitosan could be conserved without alteration. Treatment of chitin using strong aqueous $\mathrm{HCl}$ improves its solubilization capacity. It can be used to convert the solid state of $\beta$-chitin to $\alpha$-chitin [16]. The important enzymatic and chemical transformation properties of chitin are based on the molecular form ( $\alpha$-chitin or $\beta$-chitin). In light of numerous investigations, the $\alpha$-form has been found to be less responsive than the $\beta$-form [16].

In the presence of amino groups, the $\mathrm{pH}$ alters the charged state and the properties of chitosan [17]. These amines are protonated at low $\mathrm{pH}$ and charge positively, making chitosan a cationic water-soluble polyelectrolyte [14]. However, increasing the $\mathrm{pH}$ above 6 causes the chitosan polymer to lose its charge, be insoluble, and deprotonate its amines [14]. The soluble-insoluble transition occurs at a pKa value between $\mathrm{pH} 6$ and 6.5 [14]. Treating chitin with an alkaline solution allows obtaining chitosan with fibers having a resistance similar to those of viscose fibers [18]. To avoid solvent removal problems, the chitosan treatment was carried out with environmentally friendly reagents.

Chitosan was obtained from shrimp exoskeleton in two steps $[19,20]$. Chitin was extracted from shrimp shells from which chitosan were subsequently recovered. Details are as follows:

\subsubsection{Obtaining Chitin}

Shrimp shell powder $(160 \mathrm{~g})$ was treated with $1 \mathrm{~N} \mathrm{HCl}$ (Sigma-Aldrich, Saint-Louis, MO, USA) (1 L) for $2 \mathrm{~h}$ at $50{ }^{\circ} \mathrm{C}$ to remove minerals, and then filtered and washed until the $\mathrm{pH}$ of the filtrate was neutral. The filtered powder was dried at $200^{\circ} \mathrm{C}$ for $4 \mathrm{~h}$ and digested further with $2.5 \mathrm{~N} \mathrm{NaOH}$ for $2 \mathrm{~h}$ at $50^{\circ} \mathrm{C}$ to remove proteins and other macromolecules, and then filtered and washed many times until a neutral $\mathrm{pH}$. The chitin was dried in an oven at $80{ }^{\circ} \mathrm{C}$ for $24 \mathrm{~h}$ and bleached with $5 \%$ of $\mathrm{NaClO}$ (ACE, Pescara, Italy) 1:10 for $30 \mathrm{~min}$ before extracting chitosan.

\subsubsection{Obtaining Chitosan}

The bleached chitin was treated with sodium hydroxide solution of $12 \mathrm{~N}$ (SigmaAldrich, Saint-Louis, MO, USA) in an oil bath for approximately $4 \mathrm{~h}$ at $140{ }^{\circ} \mathrm{C}$, filtered, and adjusted using $\mathrm{HCl}$ until neutral $\mathrm{pH}$. The solution was placed in an oven for $4 \mathrm{~h}$ at $70^{\circ} \mathrm{C}$ and removed in a liquid state (Figure $1 b$ ).

The chitin/chitosan solubility problem complicates their extraction. Liquid chitosan was used without solubilization to assess its performance.

\subsection{X-ray Diffraction (XRD)}

The structure of raw shrimp shell powder was characterized using an X-ray diffractometer (Bruker D8 Twin, Jena, Germany), using monochromatic $\lambda(\mathrm{K} \alpha \mathrm{Cu})=1.5418 \AA$ radiation at $40 \mathrm{kV}$ and $40 \mathrm{~mA}$. All of the samples were tested in the range $3^{\circ}<2 \theta<60^{\circ}$, at a step size of $0.02^{\circ}$, and a scan rate of $0.3 \mathrm{~s} / \mathrm{step}$.

\subsection{Fourier Transforms Infrared Spectroscopy (FTIR)}

The Fourier transform infrared (FTIR) spectra of all the produced samples were examined using attenuated total reflection Fourier transform infrared spectroscopy (ATRFTIR, SHIMADZU, IRAffinity-1S, Paris, France). This device was equipped with a Jasco ATR PRO ONE module (Jasco, Paris, France) with $16 \mathrm{~cm}^{-1}$ resolution at room temperature in the wavelength spectrum from $4000 \mathrm{~cm}^{-1}$ to $400 \mathrm{~cm}^{-1}$. 


\subsection{Scanning Electron Microscopy and Energy-Dispersive X-ray Spectroscopy (SEM/EDX)}

The surface morphology of raw shrimp shells was observed using a scanning electron microscope (SEM) Supra 40 Vp Gemini Zeiss Column (SEM, JEOL, JSM-IT200), with a maximum voltage of $20 \mathrm{kV}$. The elemental composition of the sample was evaluated using the associated energy dispersive X-ray analysis (EDX) coupled with SEM (JEOL, Akishima, Tokyo, Japan).

\subsection{Jar-Test}

Raw FPW (500 mL) was placed in six $1 \mathrm{~L}$ glass beakers to examine the dosages of chitosan and the $\mathrm{pH}$ required for the optimum performance. The coagulant dosages initially selected ranged from 3 to $9 \mathrm{~mL}$. The dosages were further examined at various $\mathrm{pH}$ conditions to test their efficiency and suitability at a wider range, from 3 to 12 . The test was carried out in three phases: an initial rapid mixing for $5 \mathrm{~min}$, followed by a slow mixing for $20 \mathrm{~min}$, and finely a final settling step for $30 \mathrm{~min}$. After this, the supernatant was withdrawn for analyses. To assess the efficacy of chitosan for wastewater treatment, the following characteristics were determined: turbidity, temperature, $\mathrm{pH}$, conductivity, and $\mathrm{BOD}_{5}$. The process efficiency was presented in terms of removal rate (R) for each parameter (turbidity and $\mathrm{BOD}_{5}$ ) and was calculated using the following equation:

$$
\text { Removal Rate }[\%]=\frac{(\mathrm{C} i-\mathrm{C} f)}{\mathrm{C} i} \times 100 \%
$$

where: $\mathrm{C} i$ and $\mathrm{C} f$ are the initial and final values, respectively, for each studied parameter.

\subsection{Analytical Methods}

In order to optimize the FPW treatment using the biocoagulation process, the following three factors were taken into consideration as input variables in the experimental design model: coagulant concentration $\left(X_{1}\right)$, initial $\mathrm{pH}\left(X_{2}\right)$, and temperature $\left(X_{3}\right)$. Table 1 shows the levels of the parameters chosen on the basis of preliminary tests. The coagulant concentration was limited to the range between 3 and $9 \mathrm{mg} / 0.5 \mathrm{~L}$ due to the lack of efficacy below/above these concentrations. Either deficiency or excess of positive charges added to the pollutants influence on the coagulation capacity. The $\mathrm{pH}$ as a parameter influencing the present process was limited to the alkaline medium, taking into consideration the biocoagulant effectiveness for this type of wastewater. However, cationic coagulants, such as chitosan, have been shown to be effective at higher temperature in the treatment of wastewater.

Table 1. The range and levels of experimental variables (parameters).

\begin{tabular}{ccccc}
\hline \multirow{2}{*}{ Coded Variables } & Parameters & \multicolumn{3}{c}{ Coded Level } \\
\cline { 3 - 5 } & & $\mathbf{- 1}$ & $\mathbf{0}$ & $\mathbf{+ 1}$ \\
\hline $\mathrm{X}_{1}$ & coagulant concentration $(\mathrm{mg} / 0.5 \mathrm{~L})$ & 3 & 6 & 9 \\
$\mathrm{X}_{2}$ & initial $\mathrm{pH}$ & 8 & 10 & 12 \\
$\mathrm{X}_{3}$ & temperature $\left({ }^{\circ} \mathrm{C}\right)$ & 16 & 20 & 24 \\
\hline
\end{tabular}

The experimental design, coefficient determination of the obtained models, data analysis, and 2D and 3D graphical plots were obtained using NemrodW software (Version 2000-D, LPRAI, Marseille, France) (Table 2). The experiments were performed in random order to avoid a systematic error. In addition, three central replicates were also added to the experimental design, to calculate the pure experimental error [21]. In this study, a full threelevel Box-Behnken factorial design was used [22]. The response surface and the desirability function were used to define the design space and find the optimal conditions. The turbidity $\left(\mathrm{Y}_{1}\right)$ and $\mathrm{BOD}_{5}\left(\mathrm{Y}_{2}\right)$ deletions were considered as the responses of the designed experiments. A total of 15 experiments were performed. In order to estimate the optimal conditions, the 
response variable was fitted by an empirical second-order polynomial model, established using a response surface methodology in the form of the following equation:

$$
\mathrm{Y}=\alpha 0 \sum_{\mathrm{i}=1}^{\mathrm{k}} \alpha 1 \mathrm{sp}+\sum_{\mathrm{i}=1}^{\mathrm{k}-1} \sum_{\mathrm{j}=2}^{\mathrm{K}} \alpha 2 \text { spons }+\sum_{\mathrm{i}=1}^{\mathrm{k}} \alpha 1 \mathrm{~s} \mathrm{Xi}^{2}+\varepsilon
$$

where $\alpha 0, \alpha \mathrm{i}, \alpha \mathrm{ii}$, and $\alpha \mathrm{ij}$ are the regression coefficients for the intercept, linear, quadratic, and interaction terms, respectively; $X_{i}$ and $X_{j}$ are the independent variables (experimental parameters); and $\varepsilon$ is the error [23].

Table 2. Experimental design matrix for FPW treatment through biocoagulation.

\begin{tabular}{|c|c|c|c|c|c|}
\hline \multirow[b]{2}{*}{$\begin{array}{c}\text { Run } \\
\text { No. }\end{array}$} & \multicolumn{3}{|c|}{ Experimental Parameters } & \multicolumn{2}{|c|}{ Responses } \\
\hline & 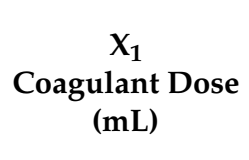 & $\begin{array}{c}\mathrm{X}_{2} \\
\text { Initial } \mathrm{pH}\end{array}$ & $\begin{array}{c}X_{3} \\
\text { Temperature } \\
\left({ }^{\circ} \mathrm{C}\right)\end{array}$ & $\begin{array}{c}\mathrm{Y}_{1} \\
\text { Turbidity } \\
\text { Removal } \\
(\%)\end{array}$ & $\begin{array}{c}\mathrm{Y}_{2} \\
\text { BOD }_{5} \\
\text { Removal (\%) }\end{array}$ \\
\hline 1 & 3.00 & 8.00 & 20.00 & 93.40 & 39.52 \\
\hline 2 & 9.00 & 8.00 & 20.00 & 89.10 & 26.74 \\
\hline 3 & 3.00 & 12.00 & 20.00 & 95.90 & 50.23 \\
\hline 4 & 9.00 & 12.00 & 20.00 & 94.66 & 35.40 \\
\hline 5 & 3.00 & 10.00 & 16.00 & 92.97 & 31.21 \\
\hline 6 & 9.00 & 10.00 & 16.00 & 86.88 & 18.39 \\
\hline 7 & 3.00 & 10.00 & 24.00 & 94.54 & 39.33 \\
\hline 8 & 9.00 & 10.00 & 24.00 & 93.11 & 20.90 \\
\hline 9 & 6.00 & 8.00 & 16.00 & 91.54 & 26.10 \\
\hline 10 & 6.00 & 12.00 & 16.00 & 95.42 & 47.76 \\
\hline 11 & 6.00 & 8.00 & 24.00 & 97.90 & 40.53 \\
\hline 12 & 6.00 & 12.00 & 24.00 & 97.81 & 46.86 \\
\hline 13 & 6.00 & 10.00 & 20.00 & 98.30 & 53.39 \\
\hline 14 & 6.00 & 10.00 & 20.00 & 98.32 & 53.50 \\
\hline 15 & 6.00 & 10.00 & 20.00 & 98.31 & 53.61 \\
\hline
\end{tabular}

\section{Results and Discussion}

The initial parameters of the raw wastewater used in this study are provided in Table 3. In accordance with Moroccan environmental legislation, the presented values for all water quality indicators, except the $\mathrm{pH}$, exceeded the discharge limits into natural effluents [24].

Table 3. Physicochemical characterization of FPW.

\begin{tabular}{|c|c|c|c|c|}
\hline \multirow{2}{*}{ Parameter } & \multicolumn{3}{|c|}{ Value } & \multirow{2}{*}{$\begin{array}{l}\text { Moroccan Standard Limits for Direct } \\
\text { Discharge into Effluents [24] }\end{array}$} \\
\hline & Min & Mean & Max & \\
\hline temperature & 12 & 18.5 & 25 & $30^{\circ} \mathrm{C}$ \\
\hline $\mathrm{pH}$ & 6.62 & 7.06 & 7.50 & $5.5-9.5$ \\
\hline conductivity & 9000 & 15,500 & 22,000 & $2700 \mu \mathrm{S} / \mathrm{cm}$ \\
\hline turbidity & 850 & 925 & $>1000$ & - \\
\hline $\mathrm{BOD}_{5}$ & 1700 & 2345.5 & 2990.9 & $100 \mathrm{mg} \mathrm{O}_{2} / \mathrm{L}$ \\
\hline
\end{tabular}

\subsection{Shrimp Shell Characterization}

\subsubsection{Analysis by Scanning Electron Microscope}

The different mixtures of raw shrimp shells were observed to identify the elemental composition of the material (Figures 2 and 3). Various structures visualized by SEM were analyzed using EDX-SEM images. Figure $2 \mathrm{a}-\mathrm{c}$ shows that the dried biomaterial was not homogeneous. The surface of Figure $2 \mathrm{a}, \mathrm{b}$ has a relatively smooth and, therefore, less porous surface. Figure $2 \mathrm{c}$ shows a microporous and rough surface structure with different sizes and morphologies of grain. 


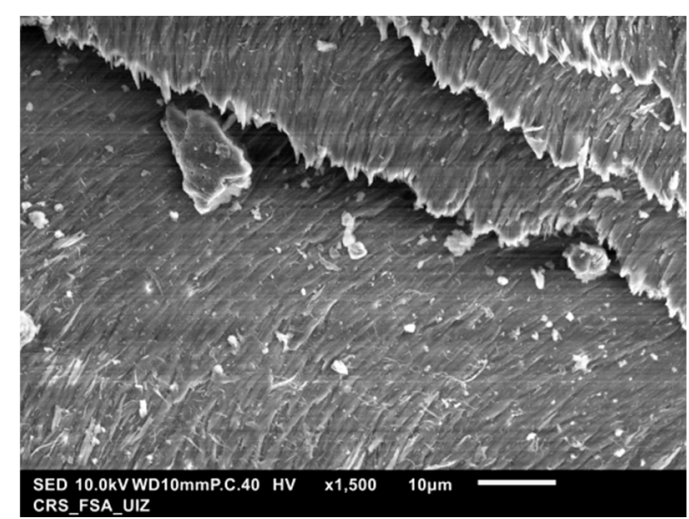

(a)

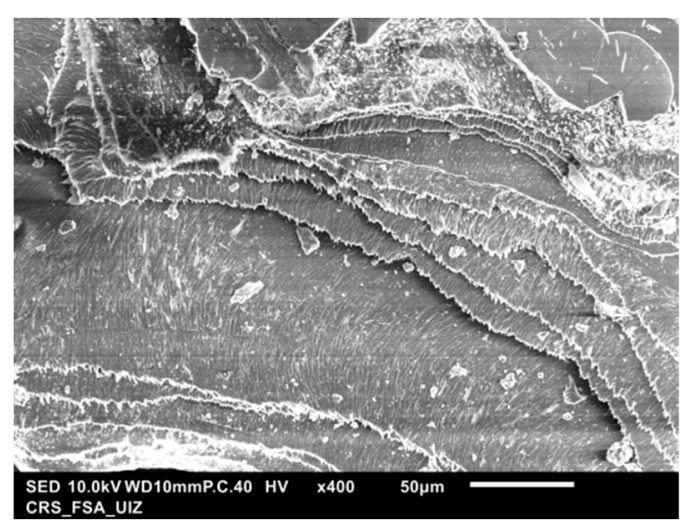

(b)

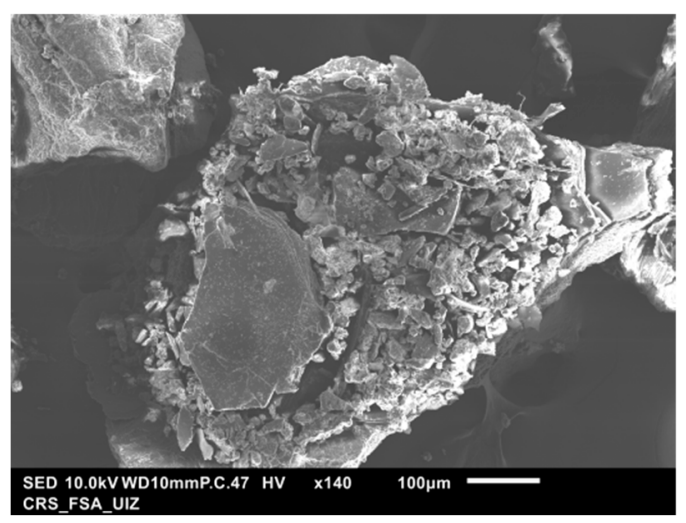

(c)

Figure 2. Scanning electron microscope image (SEM) of the raw shrimp shells (a): $10 \mu \mathrm{m},(\mathbf{b}): 50 \mu \mathrm{m},(\mathbf{c}): 100 \mu \mathrm{m}$.

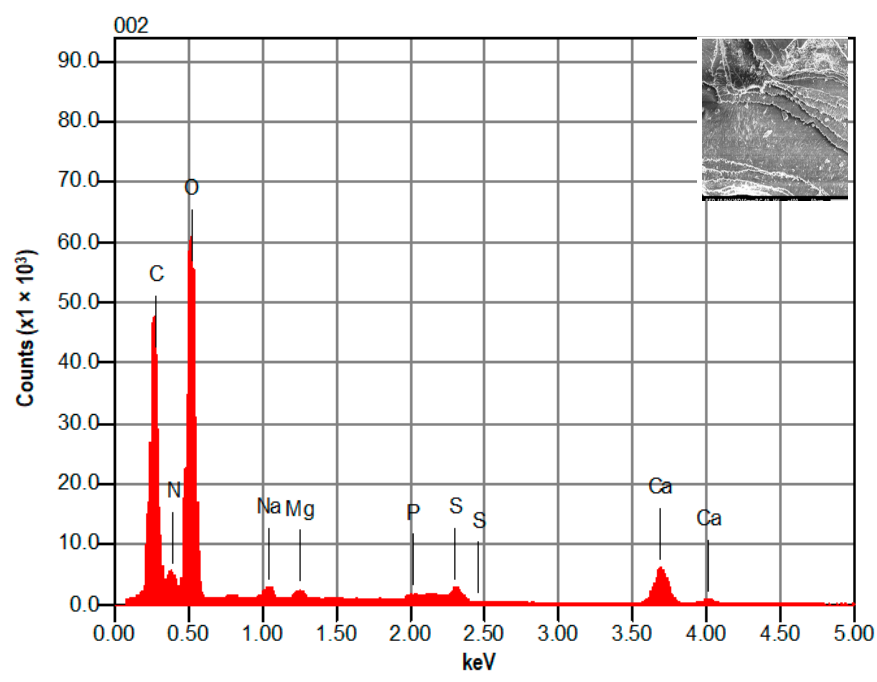

(a)

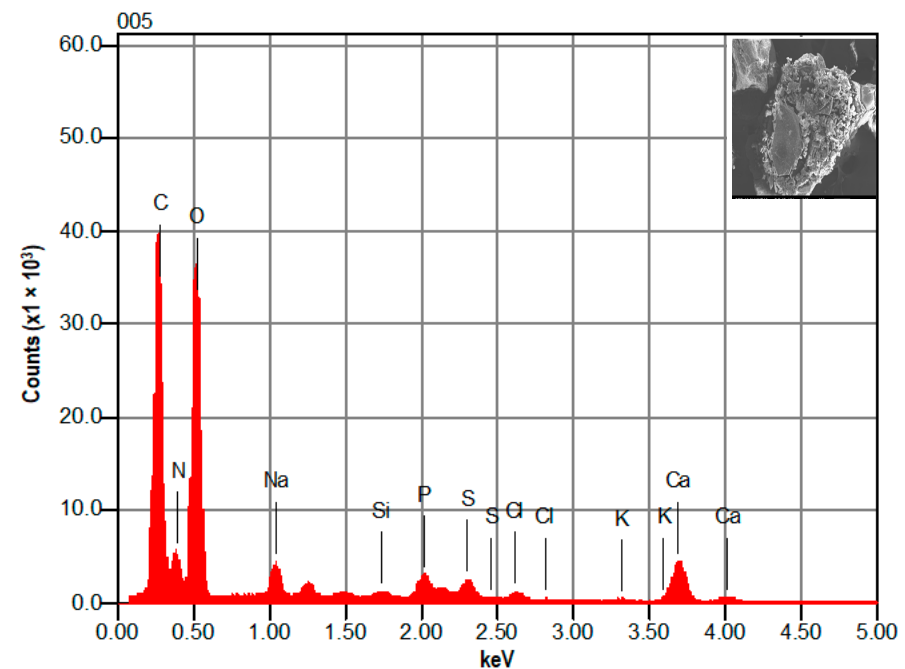

(b)

Figure 3. EDX spectrum of raw shrimp shell: (a) for $10 \mu \mathrm{m}$ SEM image and (b): for $50 \mu \mathrm{m}$ SEM image.

The presence of holes on the specific surface corresponds to the pores present in the third image (Figure 2c). The morphology of this biomaterial can facilitate the adsorption of anions and metallic elements, due to the irregular surface [25]. 
3.1.2. Scanning Electron Microscopy and Energy-Dispersive X-ray Spectroscopy (SEM/EDX)

As seen in Figure 3, the EDX analysis for Figure $2 b$ with a smooth surface and Figure 2c with a rough surface show similar elements. Only $\mathrm{C}, \mathrm{O}$, and Ca signals could be observed; these are known as the main components of raw shrimp shells. The cations, $\mathrm{Na}, \mathrm{Mg}, \mathrm{P}, \mathrm{Si}$, $\mathrm{Cl}, \mathrm{K}$, and $\mathrm{N}$ were found in very small quantities.

Chitin exists in raw shrimp shells in two different abundant polymorphic forms ( $\alpha$ and $\beta$ ). The chitin chains in both structures are presented as sheets. Several intra-sheet hydrogen bonds tightly retain chitin sheets, with $\alpha$ and $\beta$ chains packed in antiparallel arrangements [26-28]. Therefore, a tight network is formed, dominated by rather strong C-O-NH hydrogen bonds. A distance of about $0.47 \mathrm{~nm}$ is maintained in these chains [29]. Such a characteristic is not found in the structure of $\beta$-chitin, which is therefore more sensitive than $\alpha$-chitin to intracrystalline swelling [29-32]. The current model of the crystal structure of $\alpha$-chitin indicates that the inter-sheet hydrogen bonds are divided into two sets, with half-occupation in each set [29]. These aspects highlight the insolubility and intractability of chitin.

We can conclude that calcium carbonate $\mathrm{CaCO}_{3}$ is the main element of shrimp shells, according to the EDX analysis and many similar studies [33-36].

\subsubsection{Analysis by Infrared Spectroscopy}

The infrared spectrum of the raw shrimp shells (Figure 4) shows the absorption bands found in the spectrum IR of the biomolecules.

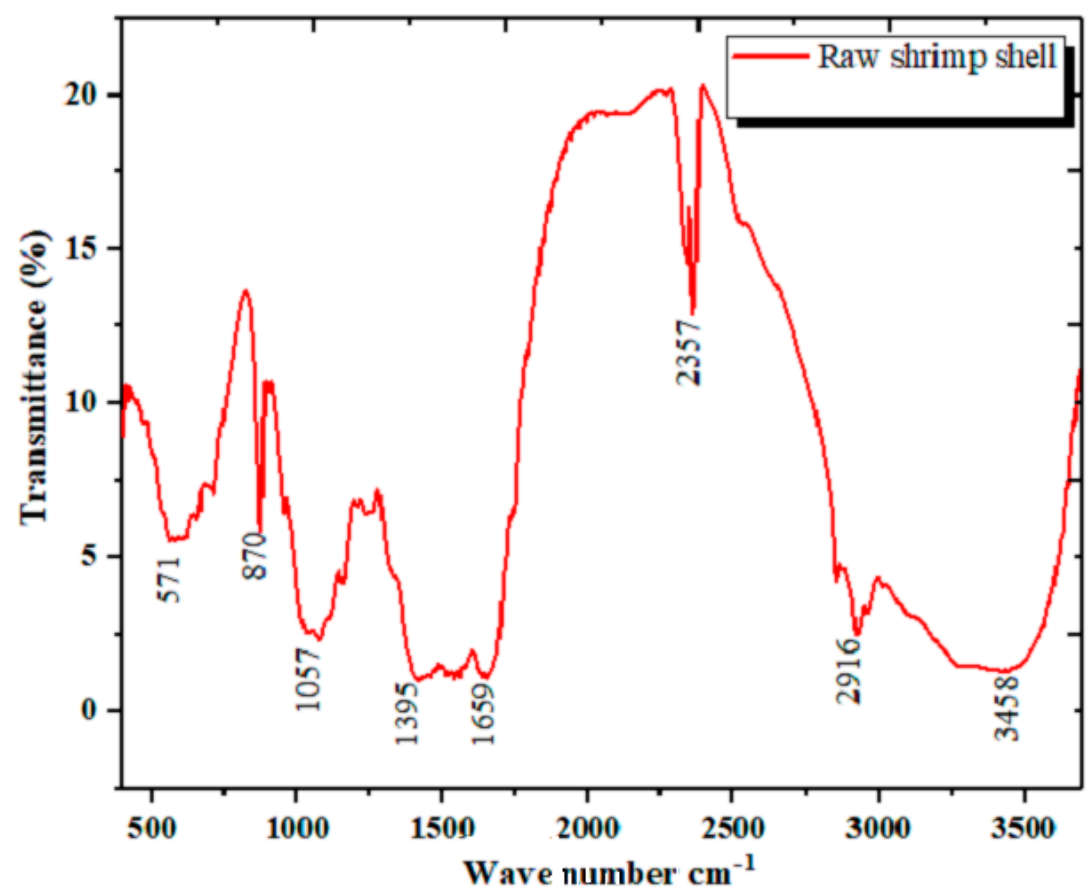

Figure 4. Infrared spectrum of raw shrimp shell.

Characteristics peaks of calcite $\left(871 \mathrm{~cm}^{-1}, 1404 \mathrm{~cm}^{-1}\right.$, and $\left.2522 \mathrm{~cm}^{-1}\right)$ were found in the IR, in addition to characteristic peaks of $\alpha$-chitin $\left(1658 \mathrm{~cm}^{-1}, 1319 \mathrm{~cm}^{-1}, 1072 \mathrm{~cm}^{-1}\right.$, $586 \mathrm{~cm}^{-1}$ ) (Figure 5) [37-42]. 


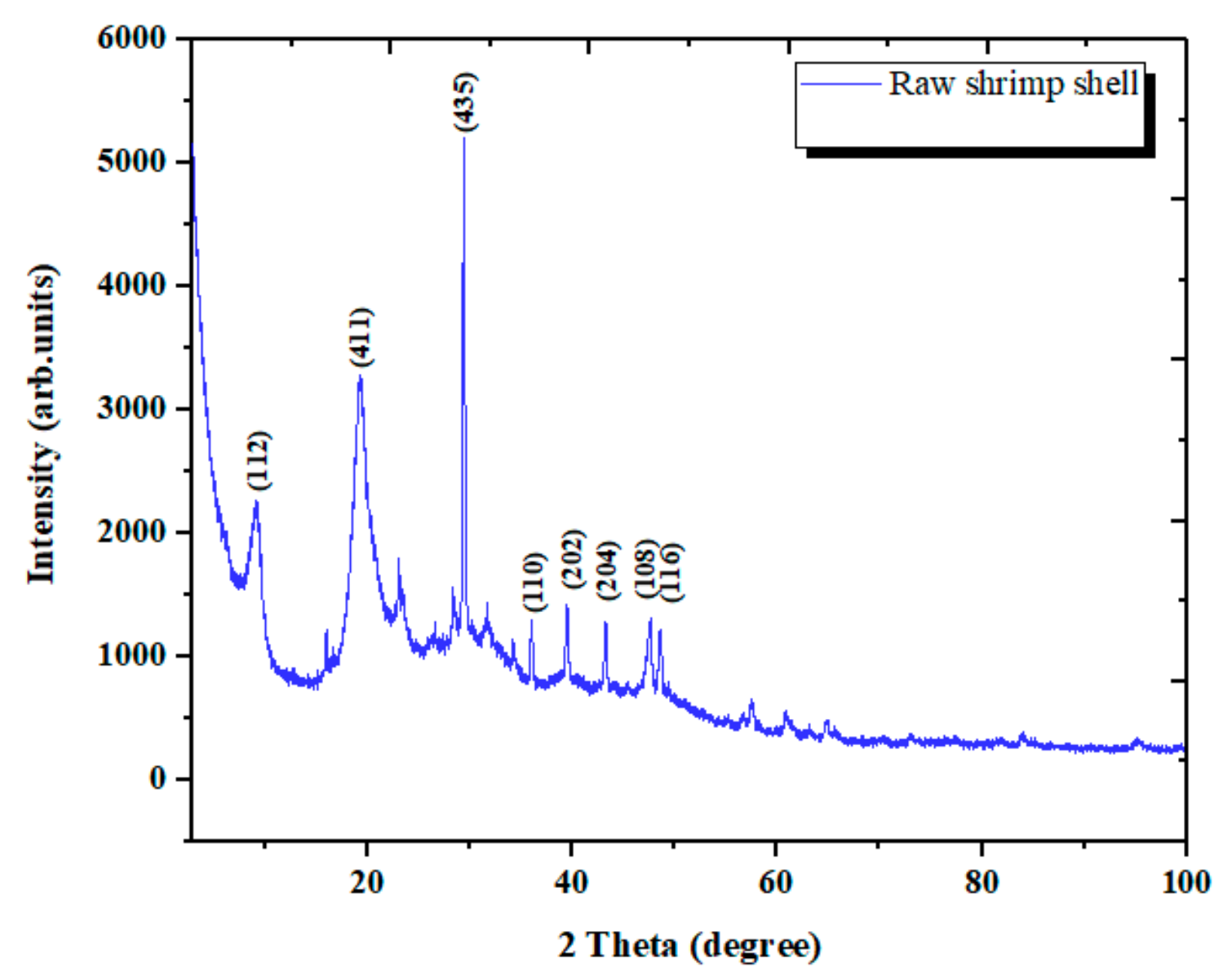

Figure 5. XRD spectrum of raw shrimp shell.

The IR confirms the presence of peaks characteristic of $(\mathrm{OH})$ hydroxyl groups and $(\mathrm{NH})$ primary amine, represented by a broadband at $3400 \mathrm{~cm}^{-1}$, which may be an attribution to the hydrogen bonds. C-H stretching vibration is also presented by two spectra: $2900 \mathrm{~cm}^{-1}$ and $1395 \mathrm{~cm}^{-1}$. A strong band at $2400 \mathrm{~cm}^{-1}$ appears in the experimental spectrum, due to the vibration band within $\mathrm{CO}_{2}$ molecules, as stated by [41,42].

The differences with the shrimp exoskeleton IR spectra in other studies may be attributed to the species of shrimp used.

\subsubsection{Analysis by XRD Spectroscopy}

The X-ray diffraction pattern for raw shrimp shells is given in Figure 5. The two mean peaks at $20^{\circ}$ and $30^{\circ}$ correspond to the diffraction planes (411) and (435), respectively. The latter peak is stronger than the first. The patterns show the presence of carbon and oxygen as the major constituents of proteins and calcium as the principal element of calcite $[43,44]$.

According to Figure 6, the majority of the peaks shown in the X-ray diffraction calcite matched the peaks of the raw shrimp shells studied. The mean peak of the diffraction revealed the nature of the material. That this biomaterial shows great compatibility, confirms the significant presence of calcite in the sample analyzed. Similar to many studies, carbonates were mostly in the form of calcium bicarbonates, as has been reported for crustacean shells $[42,45,46]$. 


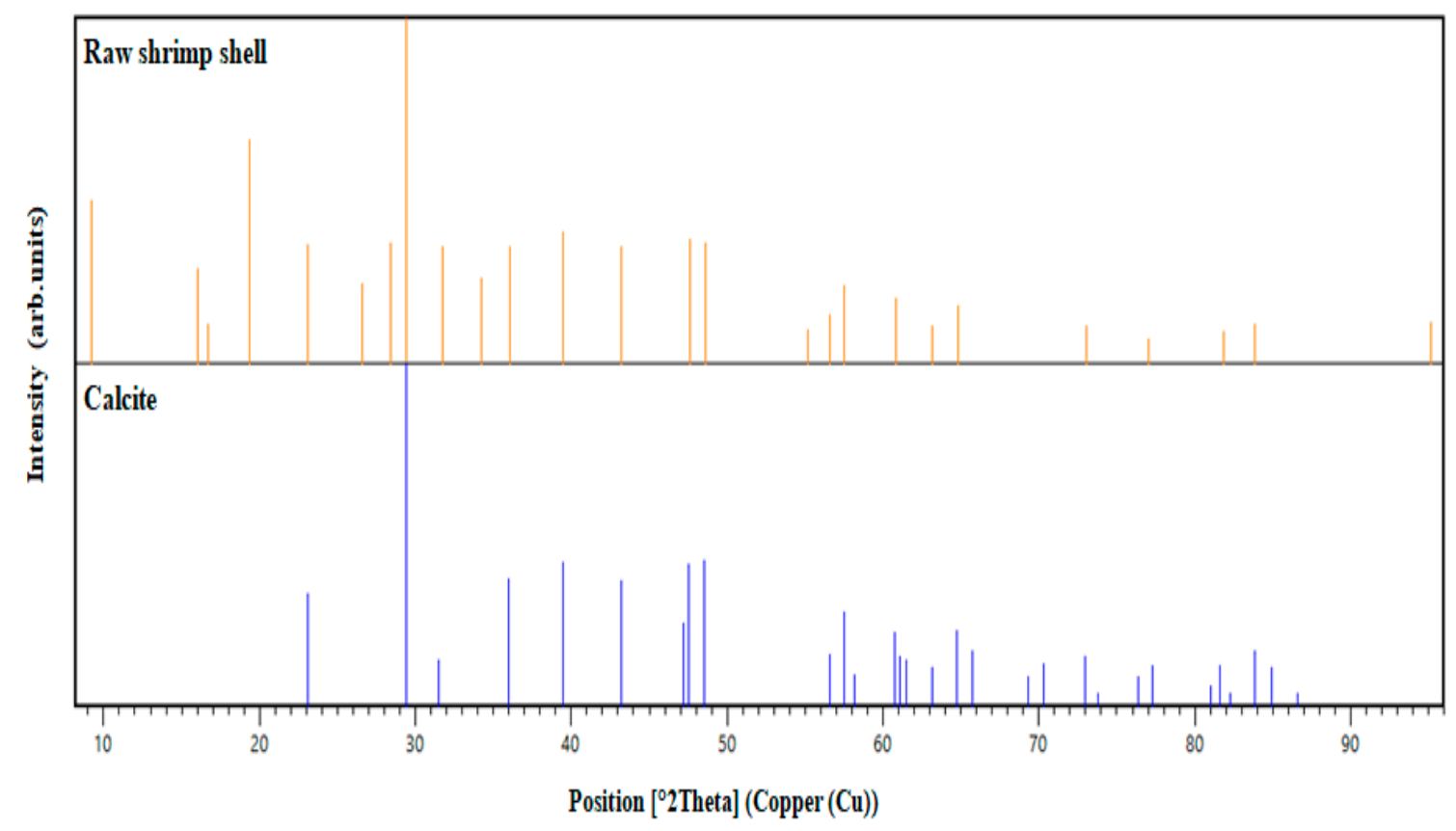

Figure 6. Comparison of XRD patterns of raw shrimp shell and calcite.

\subsection{Effect of Coagulant Dosage}

The coagulant dose is an important parameter in coagulation $[47,48]$. The optimum dosage determines the performance of the coagulants, in terms of viability and economy [49].

A lower or higher dosage than the optimum may result in insufficient coagulation and lead to lowering the effect, due to the stabilization of charges, and will not improve the efficiency further [50]. The effect of coagulant doses (from 3 to $9 \mathrm{~mL} / 0.5 \mathrm{~L}$ ) at a $30 \mathrm{~min}$ sedimentation time on the chosen parameters (turbidity and $\mathrm{BOD}_{5}$ ) with the alkaline media of the wastewater is shown in Figure 7. It can be noted that a 3 to $9 \mathrm{~mL}$ dosage worked well at alkaline $\mathrm{pH}(\mathrm{pH}=10)$, in terms of turbidity, whereas for $\mathrm{BOD}_{5}$ it required a $6 \mathrm{~mL}$ dose. The coagulating efficiency of chitosan was clear, without dissolving it in acetic acid. The nature of the treated water (fish processing wastewater) made the liquid chitosan function in the presence of sodium hydroxide, which favored the alkaline media. The chitosan particles, in combination with the dissolved sodium hydroxide particles, coagulated the pollutants presented in the FPW. The lack of efficacy of a dose greater than $6 \mathrm{~mL}$ may have been due to the destabilization of the charges, which leads to impaired coagulation. Based on these experiments, it was concluded that the $6 \mathrm{~mL}$ chitosan dosage was efficient for reducing turbidity $(98.32 \%)$ and $\mathrm{BOD}_{5}(53.5 \%)$.

Commercial chitosan has been used to treat different types of wastewater. Based on previous studies, using $1.5 \mathrm{~g} / \mathrm{L}$ of commercial chitosan to treat tanning industry wastewater reduced total suspended solids and biological oxygen demand by $89 \%$ and $33.3 \%$, respectively [51]. It has also been tested on textile wastewater, with a reduction rate of $90 \%$, in terms of turbidity reduction [50]. Another study found that treating olive oil wastewater with $400 \mathrm{mg} / \mathrm{L}$ chitosan at $\mathrm{pH} 4.3$ removed $81 \%$ of the total suspended solids [52]. 


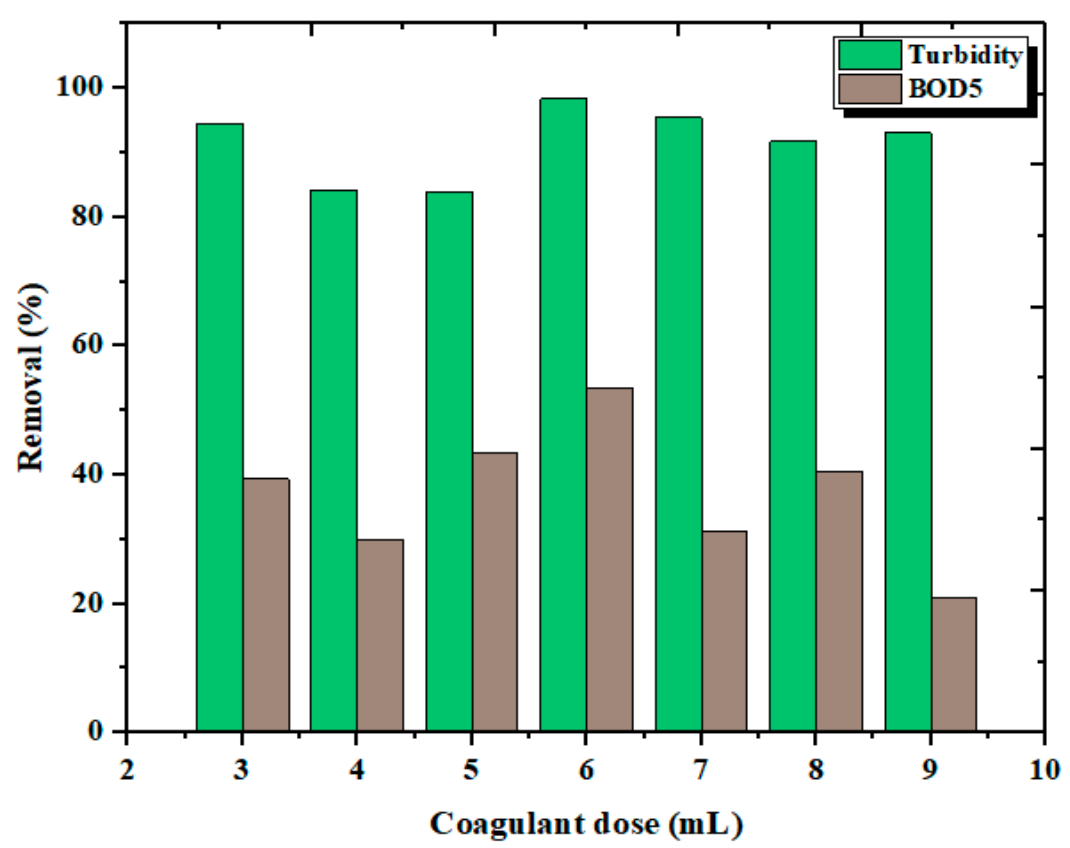

Figure 7. Effect of liquid chitosan doses on turbidity and $\mathrm{BOD}_{5}$ removal.

\subsection{Effect of $p H$}

The effect of $\mathrm{pH}$ on the turbidity removal was tested at different $\mathrm{pH}$ values, from 2 to 12. Figure 8 shows the effect of $\mathrm{pH}$ on liquid chitosan as a coagulant for turbidity removal with $30 \mathrm{~min}$ of sedimentation. It can be noted that chitosan was sensitive to $\mathrm{pH}$ changes and required near alkaline $\mathrm{pH}$ conditions for effective turbidity and $\mathrm{BOD}_{5}$ removal. A $\mathrm{pH}$ value of 10 was found to be ideal for a higher performance of chitosan for FPW. The sodium hydroxide presented in the liquid chitosan solution also had some effect, as a particle which increases the $\mathrm{pH}$ of the solution; at the same time, a large number of sodium ions dissolved in the coagulating solution as electrolytes will promote coagulation by destabilizing the system [53]. A removal efficiency of around $98 \%$ was noted in an alkaline medium $(\mathrm{pH}=10)$. Lower removal efficiencies were observed at neutral $\mathrm{pH}$, where $\mathrm{BOD}_{5}$ showed a percentage removal of $53 \%$.

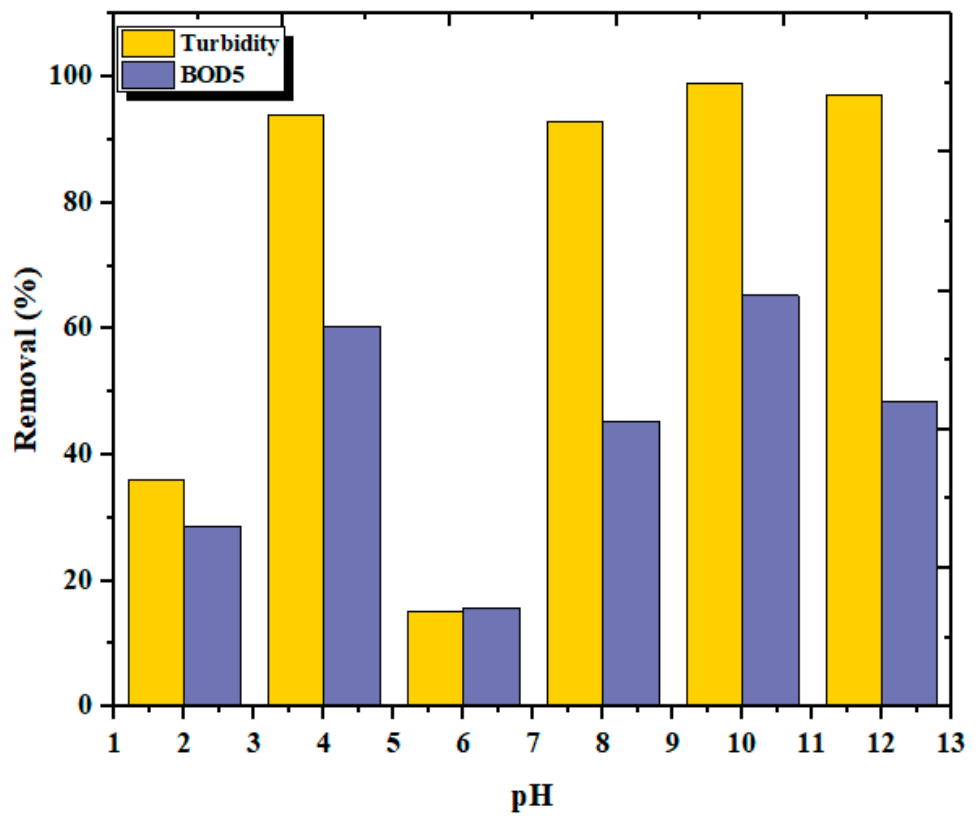

Figure 8. Effect of $\mathrm{pH}$ on the turbidity and $\mathrm{BOD}_{5}$ removal rates. 
A similar observation reported that chitosan as a coagulant has a good performance in alkaline media $[52,54,55]$. Chitosan powder as a coagulant showed a maximum removal of $26-28 \%$ of total solids at $\mathrm{pH} 5.5$. What emerged clearly from our study is that $\mathrm{pH} 6$ has a turbidity removal percentage of $15 \%$ [56]. Another study found that chitosan powder showed an effective removal of various pollutants from aquaculture wastewater through coagulation, adsorption, or disinfection [57]. Therefore, the type and quality of wastewater affects the variation in $\mathrm{pH}$ and, hence, the effectiveness of the treatment [58].

\subsection{Optimization Using a Box-Behnken Experimental Design \\ 3.4.1. Statistical Analysis}

Preliminary experiments were carried out to study the effect of the most significant parameters on the effectiveness of the FPW treatment. The relationship between the three variables (coagulant dose, initial $\mathrm{pH}$, and temperature) and the two important process responses (turbidity and $\mathrm{BOD}_{5}$ removal efficiency) for the biocoagulation process was analyzed using the surface of modeling response. In addition, the optimization of the variables studied on the basis of the experiments was carried out using the software NemrodW. The statistical analyses employed were Student's and ' $t$ ' test (Table 4).

Table 4. Statistical analysis of the regression coefficients estimated due to the FPW variation.

\begin{tabular}{|c|c|c|c|c|c|c|c|c|c|c|}
\hline & \multicolumn{2}{|c|}{ Parameter } & \multicolumn{2}{|c|}{ Standard Deviation } & \multicolumn{2}{|c|}{$\mathbf{R}_{\mathbf{2}}$} & \multicolumn{2}{|c|}{$\mathbf{R}_{2}$ Adjusted } & \multicolumn{2}{|c|}{$\mathbf{R}_{2}$ Predicted } \\
\hline & \multicolumn{2}{|c|}{ Turbidity } & \multicolumn{2}{|c|}{0.759} & \multicolumn{2}{|c|}{0.983} & \multicolumn{2}{|c|}{0.953} & \multicolumn{2}{|c|}{0.730} \\
\hline & \multicolumn{2}{|c|}{$\mathrm{BOD}_{5}$} & \multicolumn{2}{|c|}{1.549} & \multicolumn{2}{|c|}{0.994} & \multicolumn{2}{|c|}{0.984} & \multicolumn{2}{|c|}{0.906} \\
\hline \multirow{2}{*}{ Coefficient } & \multicolumn{2}{|c|}{ Value } & \multicolumn{2}{|c|}{ F. Inflation } & \multicolumn{2}{|c|}{$\begin{array}{l}\text { Standard } \\
\text { Deviation }\end{array}$} & \multicolumn{2}{|c|}{$T \operatorname{Exp}$} & \multicolumn{2}{|c|}{ Significance (\%) } \\
\hline & Turbidity & $\mathrm{BOD}_{5}$ & Turbidity & BOD $_{5}$ & Turbidity & $\mathrm{BOD}_{5}$ & Turbidity & $\mathrm{BOD}_{5}$ & Turbidity & $\mathrm{BOD}_{5}$ \\
\hline$b_{0}$ & 98.32 & 53.50 & - & - & 0.44 & 0.90 & 224.31 & 59.83 & $<0.01^{* * *}$ & $<0.01^{* * *}$ \\
\hline$b_{1}$ & -1.63 & -7.36 & 1.00 & 1.00 & 0.27 & 0.55 & -6.08 & -13.44 & $0.174^{* *}$ & $<0.01 * * *$ \\
\hline$b_{2}$ & 1.48 & 5.92 & 1.00 & 1.00 & 0.27 & 0.55 & 5.52 & 10.81 & $0.268 * *$ & $\underset{* * *}{0.0118}$ \\
\hline$b_{3}$ & 2.06 & 3.02 & 1.00 & 1.00 & 0.27 & 0.55 & 7.71 & 5.51 & $\underset{\substack{* * * \\
* *}}{0.0587}$ & $0.268^{* *}$ \\
\hline$b_{1-1}$ & -4.42 & -14.19 & 1.01 & 1.01 & 0.40 & 0.81 & -11.20 & -17.61 & $<0.01^{* * *}$ & $<0.01^{* * *}$ \\
\hline$b_{2-2}$ & -0.63 & -1.34 & 1.01 & 1.01 & 0.40 & 0.81 & -1.60 & -1.66 & 17.1 & 15.8 \\
\hline$b_{3-3}$ & -2.02 & -11.85 & 1.01 & 1.01 & 0.40 & 0.81 & -5.12 & -14.70 & $0.372 * *$ & $<0.01^{* * *}$ \\
\hline$b_{1-2}$ & 0.77 & -0.51 & 1.00 & 1.00 & 0.38 & 0.77 & 2.02 & -0.66 & 10.0 & 53.7 \\
\hline$b_{1-3}$ & 1.17 & -1.40 & 1.00 & 1.00 & 0.38 & 0.77 & 3.07 & -1.81 & $2.78 *$ & 13.0 \\
\hline$b_{2-3}$ & -0.99 & -3.83 & 1.00 & 1.00 & 0.38 & 0.77 & -2.61 & -4.95 & 4.74 * & $0.429^{* *}$ \\
\hline
\end{tabular}

*** Extremely significant; ** Very significant; * Significant.

Analysis of variance (Table 5) for turbidity and $\mathrm{BOD}_{5}$ removal shows that the fitted second-order response surface model was highly significant, with a significance value of Turbidity Signif $=0.0663^{* * *}$ and $\mathrm{BOD}_{5}$ Signif $\leq 0.01^{* * *}$.

Student's ' $\mathrm{t}$ ' test was used to determine the significance of the regression coefficients of the variables. The significance of the test reaching a value less than 0.01 indicates that the test parameter is significant at a significance level of $1 \%$ (Table 4). Compared to other studies adopting a RSM and Box-Behnken statistical analysis for the optimization of industrial wastewater treatment $[22,59,60]$, our models were considered highly significant and indicated excellent correlations between the experimental results and predicted values of BOD and turbidity removal uptake with these models. 
Table 5. Analysis of variance (NemrodW) for the models of the biocoagulation process for FPW treatment.

\begin{tabular}{|c|c|c|c|c|c|c|c|c|c|c|}
\hline \multirow{2}{*}{$\begin{array}{l}\text { Sources of } \\
\text { Variation }\end{array}$} & \multicolumn{2}{|c|}{ Sum of Squares } & \multicolumn{2}{|c|}{ Degree of Freedom } & \multicolumn{2}{|c|}{ Mean Square } & \multicolumn{2}{|c|}{ Ratio } & \multicolumn{2}{|c|}{ Significance (\%) } \\
\hline & Turbidity & BOD $_{5}$ Removal & Turbidity & $\begin{array}{c}\text { BOD }_{5} \\
\text { Removal }\end{array}$ & Turbidity & BOD $_{5}$ Removal & Turbidity & $\begin{array}{c}\text { BOD }_{5} \\
\text { Removal }\end{array}$ & Turbidity & $\begin{array}{c}\text { BOD }_{5} \\
\text { Removal }\end{array}$ \\
\hline regression & 167.68 & $2.02869 \times 10^{3}$ & 9 & 9 & 18.63 & $2.25410 \times 10^{2}$ & 32.32 & 93.95 & $0.07^{* * *}$ & $<0.01^{* * *}$ \\
\hline residual & 2.88 & $1.19955 \times 10^{1}$ & 5 & 5 & 0.58 & 2.39910 & & & & \\
\hline total & 170.56 & $2.04069 \times 10^{3}$ & 14 & 14 & & & & & & \\
\hline
\end{tabular}

3.4.2. Modeling Approach of the Response Surface to Optimize the Variables Studied

Box-Behnken statistical analysis was used to determine the single and combined effects of independent variables on the responses and outcomes, as well as on experimental conditions. According to the sum of the squares of the sequential model, the models were selected based on the highest order polynomials, where the additional terms were significant. The experimental results were evaluated and the approximation function between the FPW (Y) treatment and the variables was studied on the basis of the estimated parameters (Table 4) for turbidity and $\mathrm{BOD}_{5}(1)-(2)$, respectively:

$$
\begin{gathered}
Y_{1}=98.320-1.633 X_{1}-1.481 X_{2}-2.069 X_{3}-4.424 X_{1}^{2}-0.631 X_{2}^{2}-2.021 X_{3}^{2}+0.765 X_{1} X_{2}+1.165 X_{1} X_{3}-0.992 X_{2} X_{3} \\
Y_{2}=53.500-7.358 X_{1}+5.920 X_{2}+3.020 X_{3}-14.191 X_{1}^{2}-1.336 X_{2}^{2}-11.021 X_{3}^{2}-0.512 X_{1} X_{2}-1.402 X_{1} X_{3}-3.832 X_{2} X_{3}
\end{gathered}
$$

\subsubsection{Response Surface Plotting and Optimization of Turbidity Removal}

In order to provide a better explanation of the effects of the independent variables and their interactions, two- (2D) and three-dimensional (3D) response surface plots were drawn as a function of three parameters at a time, holding the third parameter as fixed. The following graphical representations (Figures 9-11) show the behavior of turbidity under the simultaneous change of the three variables, while fixing the third one.

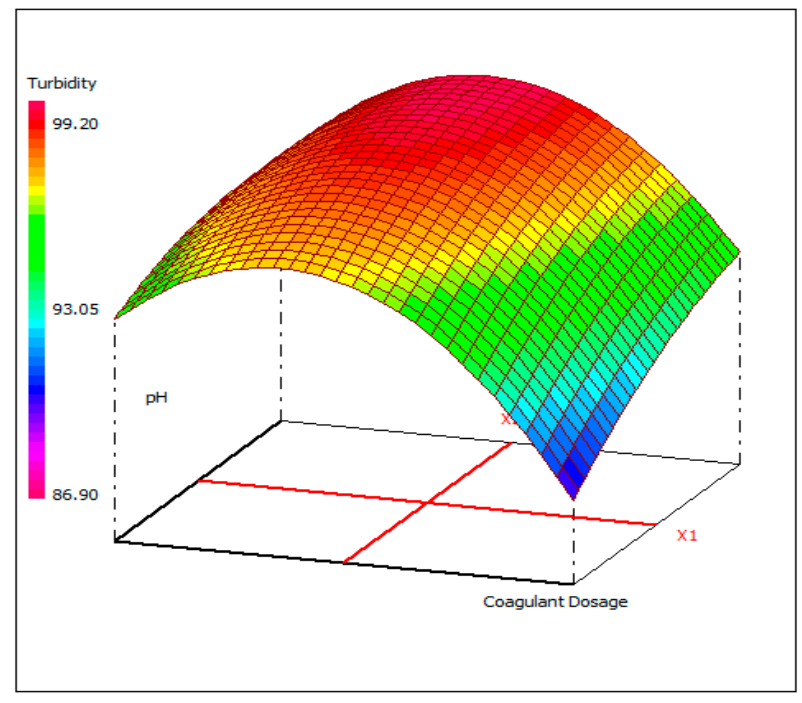

(a)

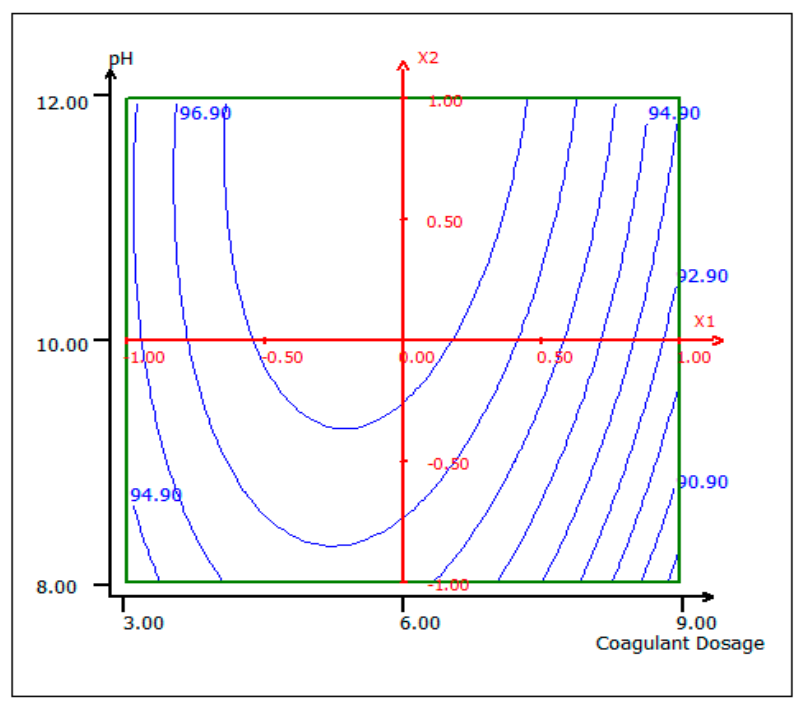

(b)

Figure 9. Three-dimensional (a) and two-dimensional (b) response surface plots for the turbidity of the treated fish processing wastewater using a biocoagulation process as a function of coagulant dose and $\mathrm{pH}$, when the temperature was maintained at $20^{\circ} \mathrm{C}$. 


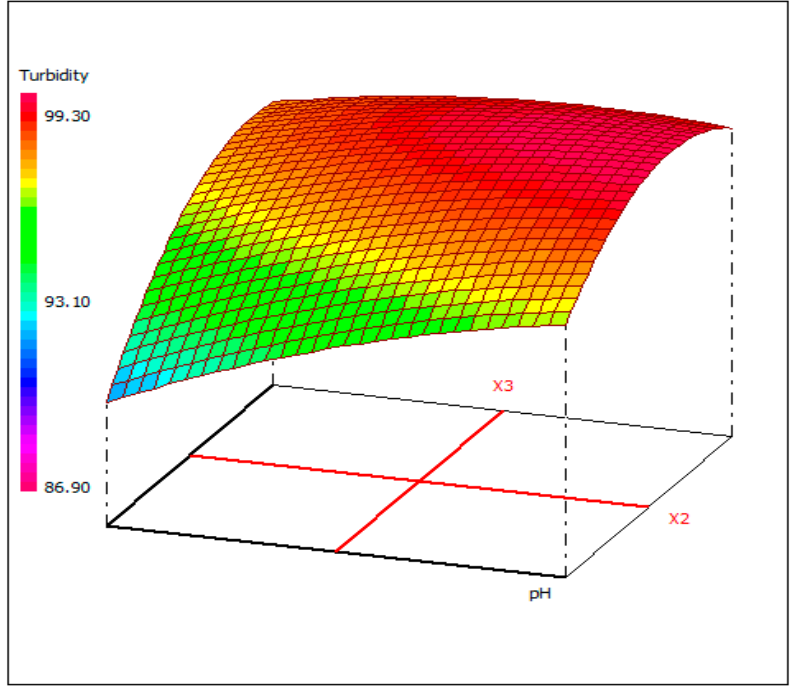

(a)

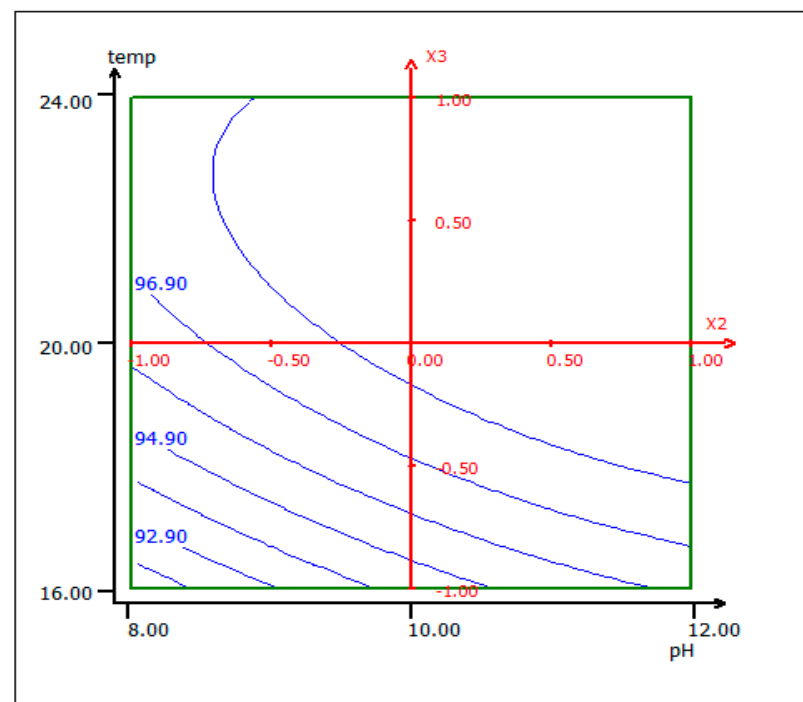

(b)

Figure 10. Three-dimensional (a) and two-dimensional (b) response surface plots for the turbidity of the treated fish processing wastewater using a biocoagulation process as a function of temperature and $\mathrm{pH}$, when the coagulant dose was maintained at $5.5 \mathrm{~mL}$.

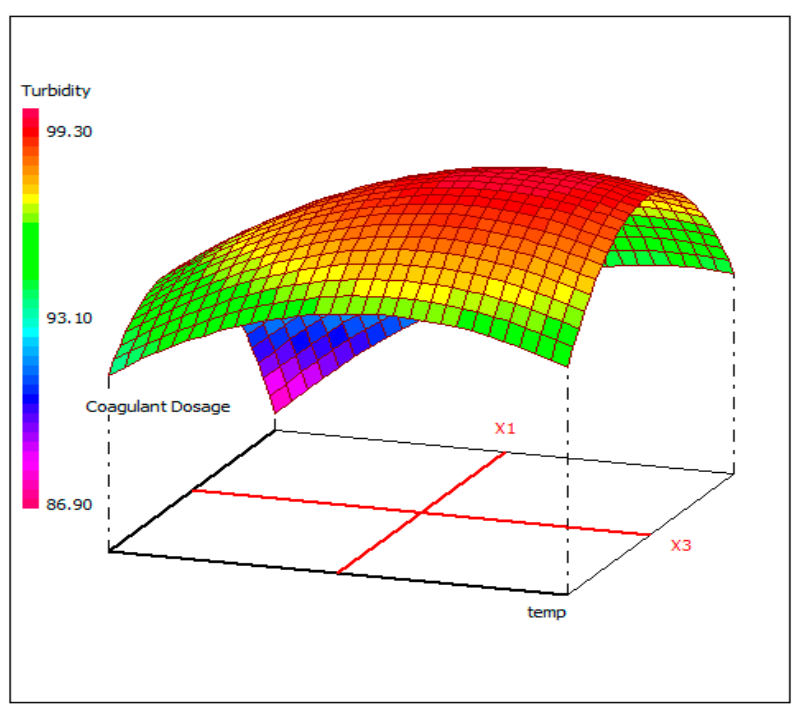

(a)

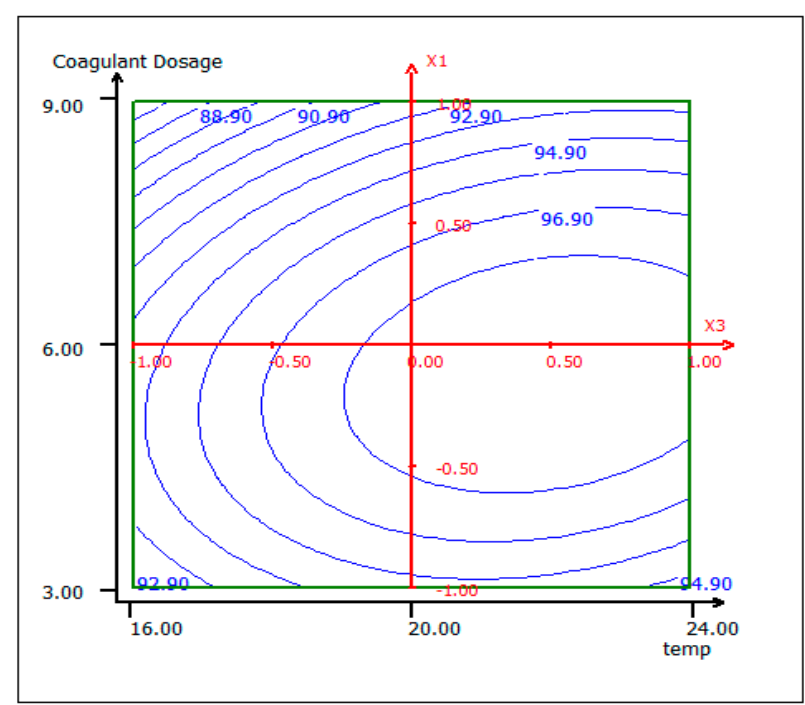

(b)

Figure 11. Three-dimensional (a) and two-dimensional (b) response surface plots for the turbidity of the treated fish processing wastewater using a biocoagulation process as a function of coagulant dose and temperature, when the $\mathrm{pH}$ was maintained at 10.5 .

As shown by the contour lines corresponding to the removal of turbidity, the shape of a dome revealed the strong interaction between the tested parameters; the depression in the response areas/surfaces indicated that the optimum conditions for maximum turbidity removal were exactly within the design limit. Thus, at a fixed $\mathrm{pH}$ of 12 , maximum turbidity removal percentages were obtained when the dose of coagulant was $5.5 \mathrm{~mL} / 500 \mathrm{~mL}$ and while the temperature was between $20^{\circ} \mathrm{C}$ and $24{ }^{\circ} \mathrm{C}$. Turbidity removal decreased when the $\mathrm{pH}$ of the wastewater was in an acid media, which could be explained by the fact that chitosan requires sufficient alkalinity to be hydrolyzed. From Figure 9, it can be deduced that the maximum elimination of turbidity was observed when the dose of coagulant was fixed at $5.5 \mathrm{~mL}$, under a fixed temperature at $20^{\circ} \mathrm{C}$, and when the $\mathrm{pH}$ varied from 10 to 12. The contour curves of the $\mathrm{pH}$ as a function of temperature at the dose of coagulant maintained at $5.5 \mathrm{~mL}$ presented in Figure 10 show that the turbidity decreases with the increase in $\mathrm{pH}$, whatever the temperature. The highest turbidity removal was obtained when the $\mathrm{pH}$ values 
were above 8 . Figure 11 shows the interaction between temperature and the coagulation dose, when the $\mathrm{pH}$ was set at 10.5. The temperature increases when the coagulant dose concentration decreases.

\subsubsection{Response Surface Plotting and Optimization of $\mathrm{BOD}_{5}$ Removal}

The response Equation (2) was used to visualize the effects of the experimental parameters on the responses under optimized conditions, using two-dimensional (b) and three-dimensional plots (a). Figures 12-14 show response surface plots of the biocoagulation of FPW as a function of two parameters, while the third was held at a constant level.

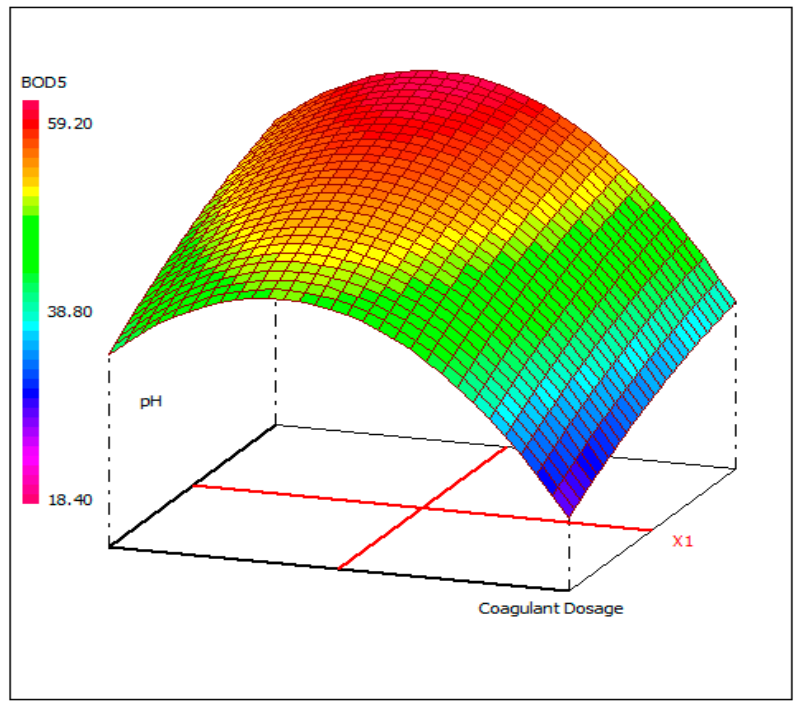

(a)

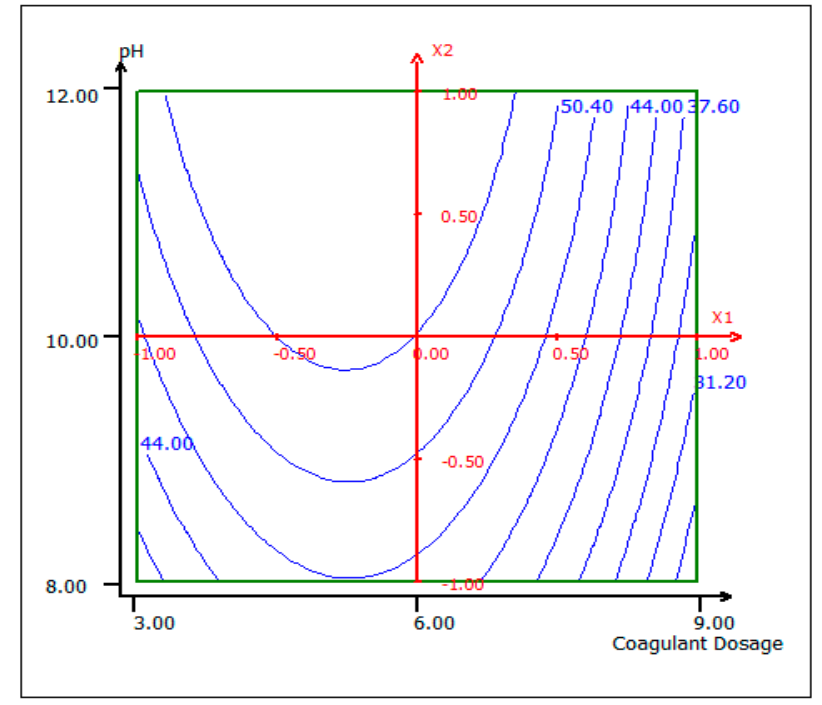

(b)

Figure 12. Three-dimensional (a) and two-dimensional (b) response surface plots for the $\mathrm{BOD}_{5}$ of the treated fish processing wastewater using a biocoagulation process as a function of coagulant dose and $\mathrm{pH}$, when the temperature was maintained at $20^{\circ} \mathrm{C}$.

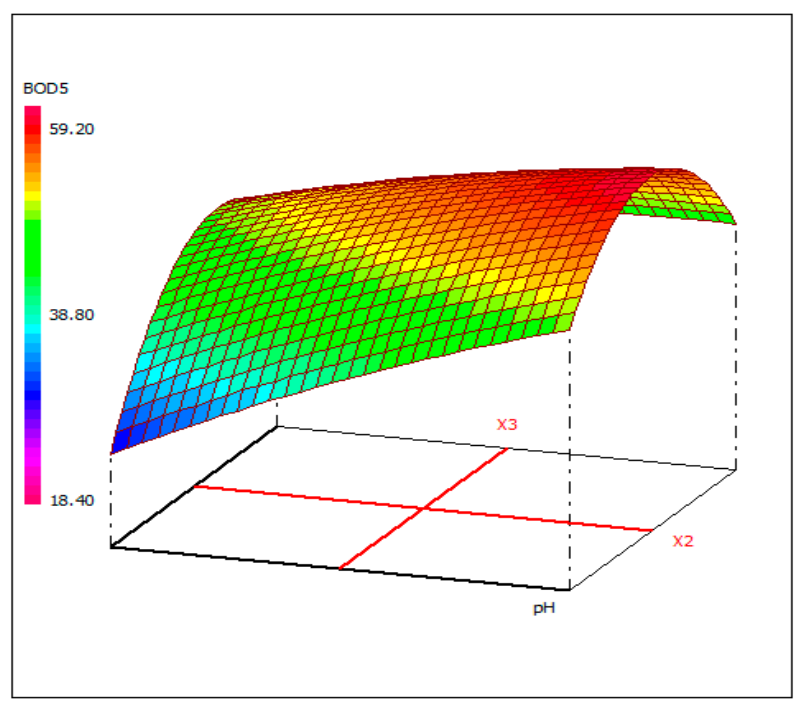

(a)

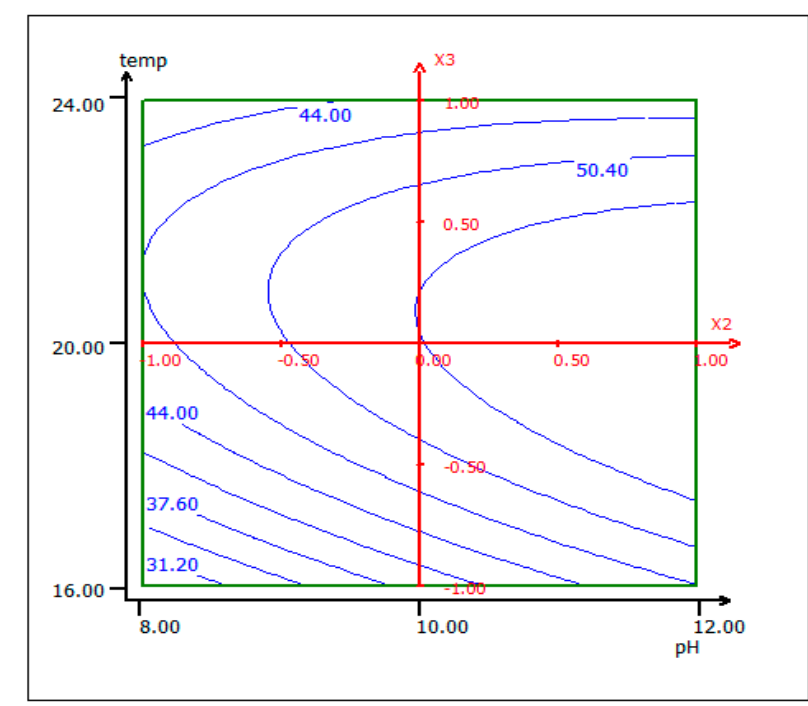

(b)

Figure 13. Three-dimensional (a) and two-dimensional (b) response surface plots for the $\mathrm{BOD}_{5}$ of the treated fish processing wastewater using a biocoagulation process as a function of temperature and $\mathrm{pH}$, when the coagulant dose was maintained around $5.5 \mathrm{~mL}$. 


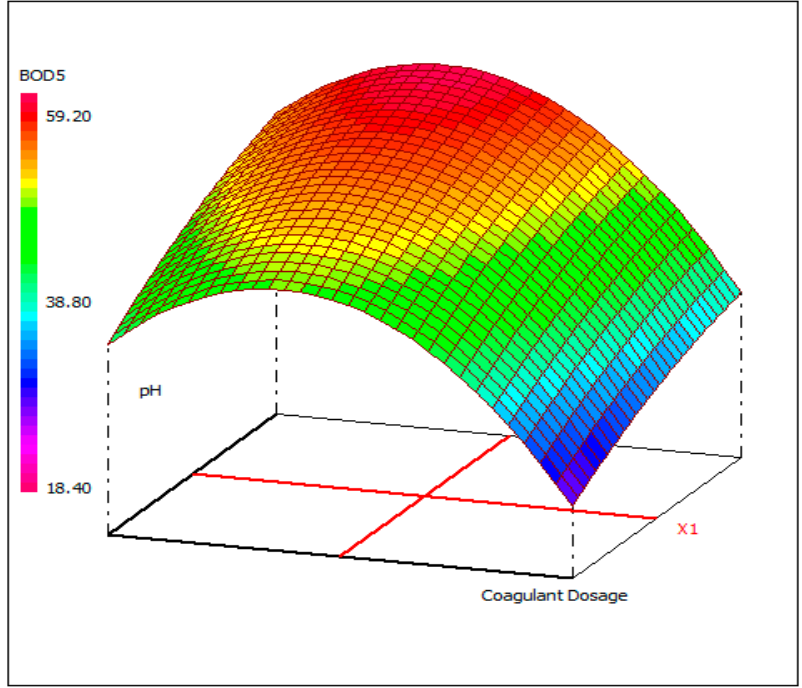

(a)

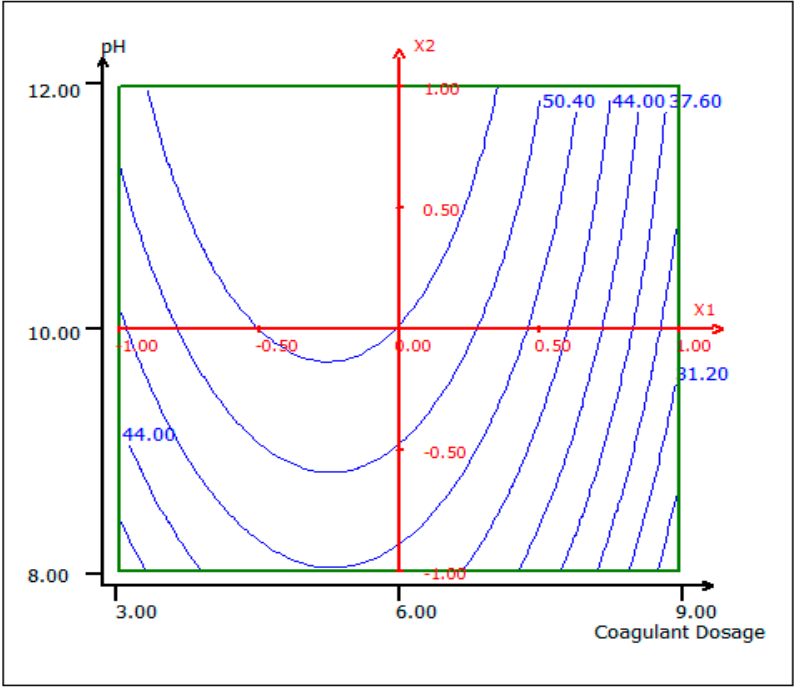

(b)

Figure 14. Three-dimensional (a) and two-dimensional (b) response surface plots for the $\mathrm{BOD}_{5}$ of the treated fish processing wastewater using a biocoagulation process as a function of coagulant dose and temperature, when the $\mathrm{pH}$ was maintained at 10.5 .

Figure 12 shows that as the $\mathrm{pH}$ increases, the removal of $\mathrm{BOD}_{5}$ increases independently of the dose of coagulant at a fixed temperature of $20^{\circ} \mathrm{C}$. When the dose of coagulant is set at $5.5 \mathrm{~mL}$, the interaction between temperature and $\mathrm{pH}$ is reciprocal (Figure 13). The $\mathrm{pH}$ increased with temperature to an optimum condition. In Figure 13, the percentage removal of $\mathrm{BOD}_{5}$ increased with $\mathrm{pH}$ and coagulant dose over a range of 5-7 mL. An approximately $90 \% \mathrm{BOD}_{5}$ removal was obtained when the dose of coagulant was set around $5.5 \mathrm{~mL}$.

The $2 \mathrm{D}$ and $3 \mathrm{D}$ surface plots show that the maximum turbidity and the elimination of $\mathrm{BOD}_{5}$ from FPW were obtained under alkaline media conditions (higher than 10.5), for a dose of coagulant of $5.5 \mathrm{~mL}$, and at a temperature between 20 and $24{ }^{\circ} \mathrm{C}$. The optimal experimental conditions for turbidity and $\mathrm{BOD}_{5}$ removal rates were obtained by analyzing the response surface contour plots (graphical analysis). However, these values were determined from a mathematical point of view, using a desirability function approach (Desirability/Monte-Carlo) [61], which gives the optimal results summarized in Table 6, for a desirability function value (D) of 0.94168 .

Table 6. The optimal experimental conditions calculated using a desirability function approach (Desirability/Monte-Carlo), and the theoretical values for $\mathrm{Y}_{1}$ and $\mathrm{Y}_{2}$.

\begin{tabular}{|c|c|c|c|c|}
\hline $\begin{array}{c}\mathrm{X}_{1} \\
\text { Coagulant } \\
\text { Concentration } \\
(\mathrm{mg} / 0.5 \mathrm{~L}) \\
\text { Coded Value } \\
\text { Real Value }\end{array}$ & $\begin{array}{c}\quad \mathrm{X}_{2} \\
\text { Initial pH } \\
\text { Coded Value } \\
\text { Real Value }\end{array}$ & $\begin{array}{c}\mathrm{X}_{3} \\
\text { Temperature } \\
\left({ }^{\circ} \mathrm{C}\right) \\
\text { Coded Value } \\
\text { Real Value }\end{array}$ & $\begin{array}{c}\mathrm{Y}_{1} \\
\text { Turbidity } \\
\text { Removal Rate } \\
(\%)\end{array}$ & $\begin{array}{c}\mathrm{Y}_{2} \\
\text { BOD }_{5} \\
\text { Removal Rate } \\
(\%)\end{array}$ \\
\hline $\begin{array}{c}-0.23982 \\
5.2805\end{array}$ & $\begin{array}{c}0.22863 \\
10.457\end{array}$ & $\begin{array}{c}-0.20584 \\
19.177\end{array}$ & 98.488 & 54.783 \\
\hline
\end{tabular}

For these established optimal conditions, the theoretical values for $\mathrm{Y}_{1}$ and $\mathrm{Y}_{2}$ were experimentally verified and repeated more than three times (confirmation run), obtaining a good concordance, confirmed by the close values: $Y_{1} \exp =98 \%$ and $Y_{2} \exp =53 \%$, respectively.

In this study case, liquid chitosan under the optimal conditions changed the dark brown color of raw FPW (Figure 15a) to significant discoloration, compared to distilled water (Figure 15c). During the biocoagulation treatment, large flocks appeared before the sedimentation phase. Thirty minutes of sedimentation phase was sufficient to remove the treated FPW without any flocculant addition. 


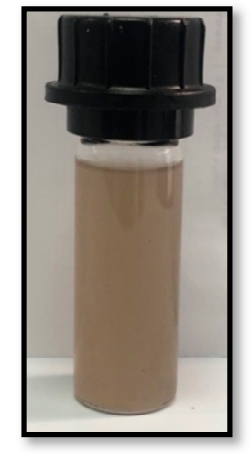

(a)

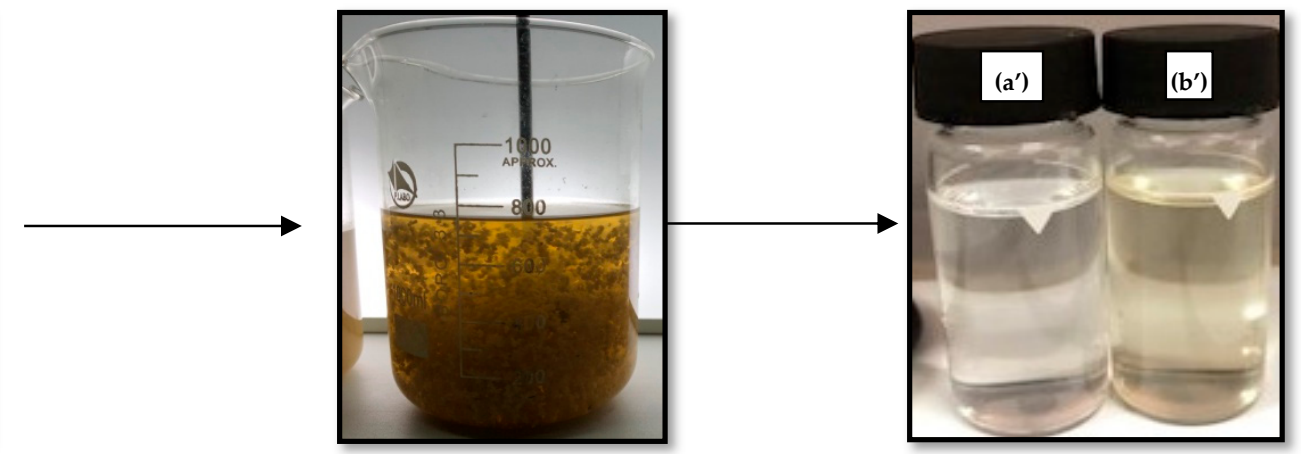

Figure 15. Representation of the discoloration process after treatment with liquid chitosan: (a) raw FPW; (b) FPW during the biocoagulation process; (c) comparison of FPW after biocoagulation using liquid chitosan ( $\left.\mathbf{b}^{\prime}\right)$ with distilled water (a').

Similar observations have been reported for large chitosan flocks in other studies. Lichtfouse and collaborators [62] reported the formation of large flocks after direct biocoagulation of wastewater. Ruhsing and collaborators [63] also reported that wastewater treated with chitosan produced the largest flocks and that the settling rate was about 1.5 times faster than that of poly-aluminum chloride.

\subsection{Comparison with Other Coagulants}

Liquid chitosan was compared to ferric chloride and commercial chitosan. The preparation of the two coagulants was made according to the optimal conditions for each one according to the literature. For ferric chloride, the optimal $\mathrm{pH}$ for fish processing industries is $\mathrm{pH}=6$. A dose optimization was carried out to define the optimal dose for this effluent $(5.5 \mathrm{~mL})$.

Commercial chitosan was studied in a wide $\mathrm{pH}$ range, from 1 to 12 . The optimum $\mathrm{pH}$ was found to be 11. Doses were also studied in the optimum $\mathrm{pH}(9 \mathrm{~mL})$.

Table 7 shows a comparative experimental study for three coagulants.

Table 7. Comparative experimental results for three coagulants used for FPW treatment.

\begin{tabular}{|c|c|c|c|c|c|}
\hline \multirow[b]{2}{*}{ Parameter } & \multirow{2}{*}{$\begin{array}{c}\text { Value } \\
\text { before } \\
\text { Treatment }\end{array}$} & \multicolumn{3}{|c|}{ Value after Treatment } & \multirow{2}{*}{$\begin{array}{c}\text { Moroccan } \\
\text { Standard Limit } \\
\text { of Direct } \\
\text { Discharge [24] }\end{array}$} \\
\hline & & $\begin{array}{c}\text { Liquid } \\
\text { Chitosan }\end{array}$ & $\begin{array}{c}\text { Ferric } \\
\text { Chloride }\end{array}$ & $\begin{array}{c}\text { Commercial } \\
\text { Chitosan }\end{array}$ & \\
\hline turbidity & $>1000$ & 10.7 & 15.6 & 13.8 & - \\
\hline $\mathrm{BOD}_{5}$ & 2990.9 & 201 & 412.5 & 209 & $100 \mathrm{mg} \mathrm{O}_{2} / \mathrm{L}$ \\
\hline
\end{tabular}

As shown in Table 7, liquid chitosan has a good cleaning ability for fish processing wastewater. In terms of turbidity, there was no significant difference between the three coagulants, while liquid chitosan and commercial chitosan showed a good reduction of the $\mathrm{BOD}_{5}$ parameter. All coagulants tested were beyond the Moroccan standard direct discharge limit. In this study, the coagulants were tested without any addition of flocculant. Therefore, the results of Table 7 are very encouraging for further study of this biocoagulant, in order to reduce the use of chemical in terms of chemical coagulants or dilution of chitosan with acetic acid (non-environmental product).

\section{Conclusions}

A novel liquid chitosan based biocoagulant for treatment of a fish processing wastewater from a Moroccan plant was successfully prepared from the most abundant fish by-product, namely shrimp shells (Parapenaeus longirostris), which was characterized using different techniques: XRD, FTIR, SEM/EDX. The use of liquid chitosan prepared from the fish solid waste will minimize the acetic acid impact on the environment and represents, at the same time, a promising solution for solid waste management. Chitosan, being a natural coagulant, respects the 'bio concept' and could be successfully used to minimize the use of chemical coagulants, being effective in the removal rate of turbidity $(98 \%)$ and $\mathrm{BOD}_{5}(53 \%)$ from fish processing wastewater. These results were obtained for 
the three most significant experimental parameters (coagulant dose, initial $\mathrm{pH}$, and temperature) of the wastewater treatment, by applying a response surface methodology using a Box-Behnken experimental design and a desirability function approach (desirability/Monte-Carlo). Therefore, the optimal experimental conditions correspond to an alkaline media $(\mathrm{pH}=10.5)$, a dose of $5.5 \mathrm{~mL}$ biocoagulantin, $0.5 \mathrm{~L}$ of fish processing wastewater, and a temperature of $20^{\circ} \mathrm{C}$.

The obtained results showed a good concordance between the experimental values and the values calculated by the prediction models, which were experimentally verified by additional confirmation run. The model validation demonstrated that the response surface methodology approach was appropriate for optimizing the biocoagulation process, in terms of the efficiency enhancement of the removal rate of turbidity and $\mathrm{BOD}_{5}$. For both of these regression equations were obtained, which could be used as models for the simulation and control of industrial wastewater treatments performed using a biocoagulation process.

Author Contributions: Conceptualization, N.N.; methodology, N.N. and N.H.; software, N.N. and I.C.; validation, N.H., N.E.A. and I.C.; formal analysis, N.N. and I.C.; investigation, N.N.; resources, N.H., N.E.A. and I.C.; data curation, N.N.; writing-original draft preparation, N.N., N.H., N.E.A. and I.C.; visualization, N.N.; supervision, N.H., N.E.A. and I.C.; project administration, N.H., N.E.A. and I.C. All authors have read and agreed to the published version of the manuscript.

Funding: This research received no external funding, except the internal grants received from "Gheorghe Asachi" Technical University of Iasi, project number GI/P14/2021 and GI/P11/2021.

Institutional Review Board Statement: Not applicable.

Informed Consent Statement: Not applicable.

Data Availability Statement: Data is contained within the article.

Acknowledgments: The authors gratefully acknowledge the support received from both Moroccan and Romanian universities.

Conflicts of Interest: The authors declare no conflict of interest.

\section{References}

1. Doukkali, M.R.; Kamili, A. Moroccan Fishery Production System and Its Dependence on the Rest of the World; OCP Policy Center: Rabat, Morocco, 2018; p. 13.

2. Sousa, S.C.; Vázquez, J.A.; Pérez-Martín, R.I.; Carvalho, A.P.; Gomes, A.M. Valorization of By-Products from Commercial Fish Species: Extraction and Chemical Properties of Skin Gelatins. Molecules 2017, 22, 1545. [CrossRef]

3. Coppola, D.; Lauritano, C.; Esposito, F.P.; Riccio, G.; Rizzo, C.; de Pescale, D. Fish Waste: From Problem to Valuable Resource. Mar. Drugs 2021, 19, 116. [CrossRef] [PubMed]

4. Taylor, P.; Elwakeel, K.Z. Environmental Application of Chitosan Resins for the Treatment of Water and Wastewater: A Review. J. Dispers. Sci. Technol. 2010, 31, 37-41.

5. Roussy, J.; Van Vooren, M.; Dempsey, B.A.; Guibal, E. Influence of chitosan characteristics on the coagulation and the flocculation of bentonite suspensions. Water Res. 2005, 39, 3247-3258. [CrossRef] [PubMed]

6. Arvanitoyannis, I.S.; Kassaveti, A. Original article Fish industry waste: Treatments, environmental impacts, current and potential uses. Int. J. Food Sci. Technol. 2008, 43, 726-745. [CrossRef]

7. No, H.K.; Meyers, S.P. Application of Chitosan for Treatment of Wastewaters. Rev. Environ. Contam. Toxicol. 2000, $163,1-28$.

8. Devi, M.G.; Jessica, J.; Feroz, S. Dairy Wastewater Treatment Using Low Molecular Weight Crab Shell Chitosan. J. Inst. Eng. India Ser. 2013, 93, 9-14. [CrossRef]

9. Thirugnanasambandham, K.; Sivakumar, V. Bagasse wastewater treatment using biopolymer-A novel approach. J. Serb. Chem. Soc. 2014, 79, 897-909. [CrossRef]

10. Venkatachalam, S. Treatment of egg processing industry effluent using chitosan as an adsorbent. J. Serb. Chem. Soc. 2014, 79, 743-757.

11. Divakaran, R.; Pillai, V.N.S. Flocculation of river silt using chitosan. Water Res. 2002, 36, 2414-2418. [CrossRef]

12. Bina, B.; Ebrahimi, A.; Hesami, F. The effectiveness of chitosan as coagulant aid in turbidity removal from water. Int. J. Environ. Health Eng. 2014, 2, 46-51. [CrossRef]

13. Rodger, B.B.; Andrew, D.E.; Eugene, W.R. Standard Methods for the Examination of Water and Wastewater, 23th ed.; American Public Health Association: Washington, DC, USA; American Water Works Association, Water Environment Federation: Denver, CO, USA, 2017; pp. 1-105.

14. Paul, W.; Pillai CK, S.; Paul, W.; Sharma, C.P. Chitin and Chitosan Polymers: Chemistry, Solubility and Fiber Formation. Prog. Polym. Sci. 2009, 34, 641-678. 
15. Zhanyong, G.; Ronge, X.; Song, L.; Zhimei, Z.; Xia, J.; Lin, W.P.L. The influence of molecular weight of quaternized chitosan on antifungal. Carbohydr. Polym. 2008, 71, 694-697.

16. Saito, Y.; Putaux, J.L.; Okano, T.; Gaill, F.; Chanzy, H. Structural aspects of the swelling of $\beta$ chitin in $\mathrm{HCl}$ and its conversion into $\alpha$ chitin. Macromolecules 1997, 30, 3867-3873. [CrossRef]

17. Yi, H.; Wu, L.Q.; Bentley, W.E.; Ghodssi, R.; Rubloff, G.W.; Culver, J.N.; Payne, G.F. Biofabrication with chitosan. Biomacromolecules 2005, 6, 2881-2894. [CrossRef]

18. Ravi Kumar, M.N.V. Chitin and chitosan fibres: A review. Bull. Mater. Sci. 1999, 22, 905-915. [CrossRef]

19. Muzzarelli, R.A.A. Carboxymethylated chitins and chitosans. Carbohydr. Polym. 1988, 8, 1-21. [CrossRef]

20. Onsosyen, E.; Skaugrud, O. Metal recovery using chitosan. J. Chem. Technol. Biotechnol. 1990, 49, 395-404. [CrossRef]

21. Louhichı, G.; Bousselmı, L.; Ghrabı, A.; Khounı, I. Process optimization via response surface methodology in the physico-chemical treatment of vegetable oil refinery wastewater. Environ. Sci. Pollut. Res. 2019, 26, 18993-19011. [CrossRef] [PubMed]

22. Khouni, I.; Marrot, B.; Ben Amar, R. Decolourization of the reconstituted dye bath effluent by commercial laccase treatment: Optimization through response surface methodology. Chem. Eng. J. 2010, 156, 121-133. [CrossRef]

23. Benyounis, K.Y.; Olabi, A.G.; Hashmi, M.S.J. Optimizing the laser-welded butt joints of medium carbon steel using RSM. J. Mater. Process. Technol. 2005, 164, 986-989. [CrossRef]

24. MEMEE. Preservation of the Quality of Water Resources and Fight against Pollution, Discharge Limit Values to Be Respected by Spills (Pollution Standards); Minister Delegate to the Minister of Energy, Mines, Water and Environment in charge of the Environment: Rabat, Morocco, 2014; p. 13.

25. Abidar, F.; Morghi, M.; Abali, M.; Sinan, F.; Chiban, M.; Eddaoudi, H.; Zebret, M. Orthophosphate ion adsorption on to raw shrimp shells. J. Water Sci. 2016, 29, 197-211.

26. Rinaudo, M. Main properties and current applications of some polysaccharides as biomaterials. Polym. Int. 2008, 57, 397-430. [CrossRef]

27. Yamaguchi, Y.; Nge, T.T.; Takemura, A.; Hori, N.; Ono, H. Characterization of uniaxially aligned chitin film by 2D FT-IR spectroscopy. Biomacromolecules 2005, 6, 1941-1947. [CrossRef]

28. Włochowicz, A.; Szosland, L.; Biniaś, D.; Szumilewicz, J. Crystalline structure and mechanical properties of wet-spun dibutyrylchitin fibers and products of their alkaline treatment. J. Appl. Polym. Sci. 2004, 94, 1861-1868. [CrossRef]

29. Minke, R.; Blackwell, J. The structure of $\alpha$-chitin. J. Mol. Biol. 1978, 120, 167-181. [CrossRef]

30. Ogawa, K.; Yui, T.; Okuyama, K. Three D structures of chitosan. Int. J. Biol. Macromol. 2004, 34, 1-8. [CrossRef] [PubMed]

31. Yui, T.; Imada, K.; Okuyama, K.; Obata, Y.; Suzuki, K.; Ogawa, K. Molecular and Crystal Structure of the Anhydrous Form of Chitosan. Macromolecules 1994, 27, 7601-7605.

32. Yui, T.; Taki, N.; Sugiyama, J.; Hayashi, S. Exhaustive crystal structure search and crystal modeling of $\beta$-chitin. Int. J. Biol. Macromol. 2007, 40, 336-344. [CrossRef] [PubMed]

33. Kurita, K. Chitin and chitosan: Functional biopolymers from marine crustaceans. Mar. Biotechnol. 2006, 8, 203-226. [CrossRef]

34. Younes, I.; Rinaudo, M. Chitin and chitosan preparation from marine sources. Structure, properties and applications. Mar. Drugs 2015, 13, 1133-1174. [CrossRef]

35. Dahmane, E.M.; Taourirte, M.; Eladlani, N.; Rhazi, M. Extraction and Characterization of Chitin and Chitosan from Parapenaeus longirostris from Moroccan Local Sources. Int. J. Polym. Anal. Charact. 2014, 19, 342-351. [CrossRef]

36. Al Sagheer, F.A.; Al-Sughayer, M.A.; Muslim, S.; Elsabee, M.Z. Extraction and characterization of chitin and chitosan from marine sources in Arabian Gulf. Carbohydr. Polym. 2009, 77, 410-419. [CrossRef]

37. Kim, S.-K. Chitin, Chitosan, Oligosaccharides and Their Derivatives Biological; Taylor \& Francis Group: Boca Raton, FL, USA, 1992; Volume 66, pp. 1360-1364.

38. Brugnerotto, J.; Lizardi, J.; Goycoolea, F.M.; Argüelles-Monal, W.; Desbrières, J.; Rinaudo, M. An infrared investigation in relation with chitin and chitosan characterization. Polymer 2001, 42, 3569-3580. [CrossRef]

39. Assaad, E. Study of the Coagulation-Flocculation Process of the Montmorillonite-Chitosan System in the Elimination of Transition Metals; University of Quebec in Montreal: Montreal, QC, Canada, 2006; pp. 1-156.

40. Arbia, W.; Adour, L.; Amrane, A.; Lounici, H. Optimization of medium composition for enhanced chitin extraction from Parapenaeus longirostris by Lactobacillus helveticus using response surface methodology. Food Hydrocoll. 2013, 31, 392-403. [CrossRef]

41. Zhu, Y.; Zhang, L.; Gu, L.; Guo, X.; Zhou, J. The zircon SHRIMP chronology and trace element geochemistry of the Carboniferous volcanic rocks in western Tianshan Mountains. Chin. Sci. Bull. 2005, 50, 2201-2212. [CrossRef]

42. Di Mario, F.; Rapanà, P.; Tomati, U.; Galli, E. Chitin and chitosan from Basidiomycetes. Int. J. Biol. Macromol. 2008, 43, 8-12. [CrossRef]

43. Arbia, W.; Arbua, L.; Adour, L.; Amrane, A.; Benhadji, A.; Lounci, H. Characterization by spectrometric methods of chitin produced from white shrimp shells of Parapenaeus longirostris by Lactobacillus helveticus cultivated on glucose or date waste. Alger. J. Envion. Sci. Technol. 2019, 5, 955-963.

44. Cárdenas, G.; Cabrera, G.; Taboada, E.; Miranda, S.P. Chitin characterization by SEM, FTIR, XRD, and13C cross polarization/mass angle spinning NMR. J. Appl. Polym. Sci. 2004, 93, 1876-1885. [CrossRef]

45. Kumari, S.; Kumar Annamareddy, S.H.; Abanti, S.; Kumar Rath, P. Physicochemical properties and characterization of chitosan synthesized from fish scales, crab and shrimp shells. Int. J. Biol. Macromol. 2017, 104, 1697-1705. [CrossRef] [PubMed] 
46. Roberts, G.A.F. Analysis of Chitin and Chitosan. Chitin Chem. 1992, 130, 1-462.

47. Basosidik, S.; Pankaew, P.; Hoonnivathana, E.; Limsuwan, P.; Naemchanthara, K. Characterization of chitin extracted from waste sources via XRD, FTIR, and TGA techniques. Adv. Mater. Res. 2012, 488, 1404-1408. [CrossRef]

48. Nouj, N.; Heddadi, N.; Azougarh, Y.; Hafid, N.; El Alem, N. A combined treatment of municipal solid waste landfill leachate using Opuntia ficus-indica cactus as coagulant and titaniferous sand as filter material. Nanotechnol. Environ. Eng. $2021,6,14$. [CrossRef]

49. Chethana, M.; Gayatri, S.L.; Vinay, B.M.; Vivek, R.V.; Raja, S. Application of biocoagulant Acanthocereus tetragonus (Triangle cactus) in dye wastewater treatment. J. Environ. Res. Dev. 2015, 9, 813-821.

50. Patel, H.; Vashi, R.T. Comparison of naturally prepared coagulants for removal of COD and color from textile wastewater. Glob. NEST J. 2013, 15, 522-528.

51. Sila, A.; Mlaik, N.; Sayari, N.; Balti, R.; Bougatef, A. Chitin and Chitosan Extracted from Shrimp Waste Using Fish Proteases Aided Process: Efficiency of Chitosan in the Treatment of Unhairing Effluents. J. Polym. Environ. 2014, 22, 78-87. [CrossRef]

52. Rizzo, L.; Lofrano, G.; Grassi, M.; Belgiorno, V. Pre-treatment of olive mill wastewater by chitosan coagulation and advanced oxidation processes. Sep. Purif. Technol. 2008, 63, 648-653. [CrossRef]

53. Park, T.; Ampunan, V.; Maeng, S.; Chung, E. Application of steel slag coated with sodium hydroxide to enhance precipitationcoagulation for phosphorus removal. Chemosphere 2017, 167, 91-97. [CrossRef]

54. Guerrero, L.; Omil, F.; Méndez, R.; Lema, J.M. Protein recovery during the overall treatment of wastewaters from fish-meal factories. Bioresour. Technol. 1998, 63, 221-229. [CrossRef]

55. García, M.A. Treatment of Wastewater from Fish Processing Industry using Chitosan Acid Salts. Int. J. Water Wastewater Treat. 2016, 2, 1-6. [CrossRef]

56. Genovese, C.V.; González, J.F. Solids removal by coagulation from fisheries waste waters. Water SA 1998, 24, 371-372.

57. Chung, Y.C. Improvement of aquaculture wastewater using chitosan of different degrees of deacetylation. Environ. Technol. 2006, 27, 1199-1208. [CrossRef] [PubMed]

58. Selmer-Olsen, E.; Ratnaweera, H.C.; Pehrson, R. A novel treatment process for dairy wastewater with chitosan produced shrimp-shell waste. Water Sci. Technol. 1996, 34, 33-40. [CrossRef]

59. Tak, B.-Y.; Tak, B.-S.; Kim, Y.-J.; Park, Y.-J.; Yoon, Y.-H.; Min, G.-H. Optimization of color and COD removal from livestock wastewater by electrocoagulation process: Application of Box-Behnken design (BBD). J. Ind. Eng. Chem. 2015, 28, 307-315. [CrossRef]

60. Elmoubarki, R.; Taoufik, M.; Moufti, A.; Tounsadi, H.; Mahjoubi, F.Z.; Bouabi, Y.; Qourzal, S.; Abdennouri, M.; Barka, N. Box-Behnken experimental design for the optimization of methylene blue adsorption onto Aleppo pine cones. J. Mater. Environ. Sci. 2017, 8, 2184-2191.

61. Cojocaru, C.; Pascariu Dorneanu, P.; Airinei, A.; Olaru, N.; Samoila, P.; Rotaru, A. Design and evaluation of electrospun polysulfone fibers and polysulfone/NiFe2O4 nanostructured composite as sorbents for oil spill cleanup. J. Taiwan Inst. Chem. Eng. 2017, 70, 267-281. [CrossRef]

62. Lichtfouse, E.; Morin-Crini, N.; Fourmentin, M.; Zemmouri, H.; do Carmo Nascimento, I.O.; Matos Queiroz, L.; Yuhyi, M.; Tadza, M.; Picos-Corrales, L.A.; Pei, H.; et al. Chitosan for direct bioflocculation of wastewater. Environ. Chem. Lett. 2019, 17, 1603-1621. [CrossRef]

63. Ruhsing Pan, J.; Huang, C.; Chen, S.; Chung, Y.C. Evaluation of a modified chitosan biopolymer for coagulation of colloidal particles. Colloids Surf. A Physicochem. Eng. Asp. 1999, 147, 359-364. [CrossRef] 